\title{
The Birth of a Connected South Atlantic Ocean: A Magnetostratigraphic Perspective
}

\author{
Dan V. Palcu ${ }^{1 *}$, Joy R. Muraszko ${ }^{1,2 *}$, Plinio F. Jaqueto ${ }^{3}$ and Luigi Jovane ${ }^{1}$ \\ ${ }^{1}$ Instituto Oceanografico, Universidade de São Paulo, São Paulo, Brazil, ${ }^{2}$ Laboratory of Orogenic Belts and Crustal \\ Evolution, School of Earth and Space Sciences, Peking University, Beijing, China, ${ }^{3}$ Instituto de Astronomia, Geofisica e \\ Ciencias Atmosfericas, Universidade de São Paulo, São Paulo, Brazil
}

OPEN ACCESS

Edited by:

Eric Font,

University of Coimbra, Portugal

Reviewed by:

Sara Satolli,

G. d'Annunzio University of Chieti and Pescara, Italy

Qingsong Liu,

Institute of Geology and Geophysics,

China

${ }^{*}$ Correspondence:

Dan V. Palcu

d.v.palcu@usp.br:

dan.palcu@gmail.com

Joy R. Muraszko

jrm220@pku.edu.cn

Specialty section:

This article was submitted to Geomagnetism and Paleomagnetism,

a section of the journal

Frontiers in Earth Science

Received: 07 April 2020

Accepted: 11 August 2020

Published: 18 September 2020

Citation:

Palcu DV, Muraszko JR

Jaqueto PF and Jovane L (2020) The Birth of a Connected South Atlantic

Ocean: A Magnetostratigraphic Perspective. Front. Earth Sci. 8:375.

doi: 10.3389/feart.2020.00375
The early Paleogene sedimentary record of the Sao Paulo Plateau holds the key to understanding the timing and mechanisms of the onset of Atlantic oceanic circulation, with implications for ocean - climate feedback systems. The timing and evolution of South Atlantic Ocean connectivity remain poorly understood, hindering a full understanding of modern circulation mechanisms. In this work, we develop an improved magnetostratigraphic age model for the late- Cretaceous to Eocene sedimentary record of Deep-Sea Drilling Project (DSDP) Site 356, located on the São Paulo Plateau at the edge of the Rio Grande Rise. The model constrains the timing of the beginning of Atlantic Ocean circulation, as the last obstacle to a connected Atlantic was removed. We use the age model to quantify sedimentary rates, and correlate with rock magnetic and published geochemical data to explore links between ocean current rearrangement and climatic anomalies. We find that periods characterized by variations in the magnetic properties of sediments and sedimentation anomalies in the Sao Paulo Plateau are reflected in carbon isotope events, supporting a possible link between ocean circulation and hyperthermal events.

Keywords: São Paulo Plateau, paleocirculation, Danian, Selandian, Rio Grande Rise, Walvis Ridge, Paleogene, hyperthermals

\section{INTRODUCTION}

Ocean circulation is one of the crucial factors driving the change of the climate in our modern world. Differences in temperature and salinity of seawater masses drive the thermohaline circulation, facilitating heat transport across the globe. One of the key components of the thermohaline circulation system is the Atlantic meridional overturning circulation (AMOC), which plays a fundamental role in Earth's climate system. The AMOC is one of the largest heat pumps and high-latitude heat sinks (Grassl, 2001; Buckley and Marshall, 2016), unique in the global oceans. The heat transport by AMOC is responsible for the relatively warm climate of the Northern Hemisphere, accounting for up to $25 \%$ of the total northward heat transport (Bryden and Imawaki, 2001; Buckley and Marshall, 2016; Chen and Tung, 2018). It is also one of the most important carbon sinks (Battle et al., 2000; Gruber et al., 2002), thus its strength is one of the regulators of climate change, with implications for understanding the consequences of anthropogenic global warming. To better understand the interplay between oceans and climate, we need to focus on the evolution of thermohaline circulation and in particular the onset of the Atlantic Ocean Circulation 
(AOC), reaching back in the geological records to the birth of the Atlantic Ocean. In this study, we aim to contribute to the understanding of how the AOC developed by focusing on the Paleogene of the South Atlantic when the last submarine obstacles began to give way to a fully connected ocean, and the heat pump was initiated.

\section{A Brief History of the South Atlantic}

The South Atlantic Ocean resulted from the breakup of Gondwanaland. In its Central sector, situated between the Rio Grande - Walvis Ridge and the Ascension Fault Zone, the complex rifting can be simplified to several key episodes that occurred in the region during the Cretaceous time. According to Chaboureau et al. (2013), between Berriasian and Barremian times (141-129 Ma), rifting occurred in the northern half of the central South Atlantic. At that time, this region was a series of deep lakes, bordered by lateral highs (Pérez-Díaz and Eagles, 2017). From the upper Barremian to middle Aptian (128-116 Ma), the rifting extended southward, and so did the lake that reached the Rio Grande Rise - Walvis Ridge (RGRWR) in the south. From the early Aptian, the realm was affected by brief marine influxes coming from the north, but by middle-upper Aptian, the whole region switched to an evaporitic regime (Chaboureau et al., 2013). The evaporitic phase of the South Atlantic ended after connectivity improved due to the development of a South-Central Atlantic passageway in the Albian-Cenomanian times (100 Ma).

While it is speculated that connections between the Brazilian Basin and Argentine Basin in the South Atlantic have existed in the form of shallow gateway(s), the south-north connectivity greatly improved by $\sim 80 \mathrm{Ma}$ when it is estimated that the Vema Channel (marked A in Figure 1) was around $2000 \mathrm{~m}$ deep (Pérez-Díaz and Eagles, 2017). According to the same authors, connections over the Rio Grande Rise (black arrows in Figure 1) continued deepening during the Campanian-Maastrichtian (83$66 \mathrm{Ma}$ ) when in addition to the existing Vema Gap (marked A and B) the Hunter Gap (marked C) started opening. This may have initiated Southern Component Water formation in the oceans of the southern hemisphere and its northward circulation toward the North Atlantic across the Central Atlantic Seaway (Donnadieu et al., 2016). Ocean-climate changes starting at the end of the Cretaceous eventually lead to the establishment of thermohaline circulation as we know it today (Murphy and Thomas, 2013; Donnadieu et al., 2016). The breaching of the Rio Grande Rise - Walvis Ridge alignment continued to intensify, and by mid-Miocene (14.5 Ma) (Woodruff and Savin, 1989), it is thought that the connection would have expanded sufficiently to allow deep-water circulation between the Brazil and Argentine basins. The Walvis Ridge remains a partial barrier up to this day, partially blocking deep water circulation between the Cape and Angola Basins.

The RGR-WR alignment is the last obstacle to be overcome for a fully connected South Atlantic. Its subsidence allowed deep-water circulation north toward the North Atlantic. Nonetheless, the exact age and progression of this major current rearrangement remains an open question, as various models suggest widely varying dates for this shift, from the Campanian
(80 Ma) (Robinson et al., 2010; Robinson and Vance, 2012), Maastrichtian (71-66 Ma) (Frank and Arthur, 1999; Murphy and Thomas, 2013; Donnadieu et al., 2016) and mid-Paleocene (60 Ma) (Voigt et al., 2013). To help improve our understanding of the evolution of ocean circulation in the South Atlantic there is a pressing need to investigate sedimentary records with robust chronology and wide geographic coverage. The Paleogene succession from the Deep-Sea Drilling Project (DSDP) Site 356 Leg 39 in the São Paulo Plateau represents such a record.

\section{The São Paulo Plateau - A Record of Early Atlantic Circulation}

The sedimentary records of the São Paulo Plateau (SPP) are key to understanding the RGR-WR region and its evolution from a sill significantly restricting water mass exchange, to a submerged elevation as it is today. The plateau is located in the proximity of the former sill zone. The bordering topographic highs have ensured nearly uninterrupted sedimentation during the late Cretaceous - early Paleogene times, recording changes in the water mass circulation between the Central and South Atlantic. The SPP itself forms a triangular-shaped elevation above the seafloor, extending up to $950 \mathrm{~km}$ off the Brazilian coastline (Perch-Nielsen et al., 1977). The southern boundary is marked by an east-west trending ridge arising due to the presence of an extensional fault. Spreading of the South Atlantic initiated to the south of the plateau, with the Rio Grande Rise - Walvis Ridge (RGR-WR) system forming an elevated barrier restricting ocean circulation. Early stages of rifting began in the AptianAlbian, which created a narrow, restricted basin favorable for the formation of evaporites. As a result, the majority of the SPP is underlain by salt deposits and diapirs. São Paulo Plateau (Site 356) was drilled during DSDP Leg 39, an Expedition developed to accommodate research along the path of the Glomar Challenger from the Norwegian Sea drilling season to an Antarctic and Southern Ocean drilling season in 1974 (Supko et al., 1977). Among other drilling objectives, an important scientific goal was to improve the understanding of paleocirculation and geological history of the South Atlantic through the analysis of sedimentary sections of the Ceará Rise, Brazil and Argentine Basins, Rio Grande Rise (RGR) and São Paulo Plateau (Site 356). The coring site is located at a water depth of $3175 \mathrm{~m}$, on a relatively stable section of the SPP escarpment, with a rough topology attributed to either diapiric structures or underlying igneous basement (Kumar and Gamboa, 1979). The location of the site in an area of restricted circulation above the abyssal plain creates favorable conditions for preserving a record of environmental fluctuations, sensitive to even minor changes in sea level and changes in ocean circulation.

We develop a magneto-bio-stratigraphic study, bridging our paleomagnetic research with biostratigraphic and geochemical studies from published records. Despite Site 356 having been drilled in the $70 \mathrm{~s}$, it remains a source of valuable geological and paleoenvironmental information. There has been extensive research conducted using the core, such as the studies of Kochhann et al. (2014), who developed an age-model for the upper Cretaceous and estimated sedimentation rates in 


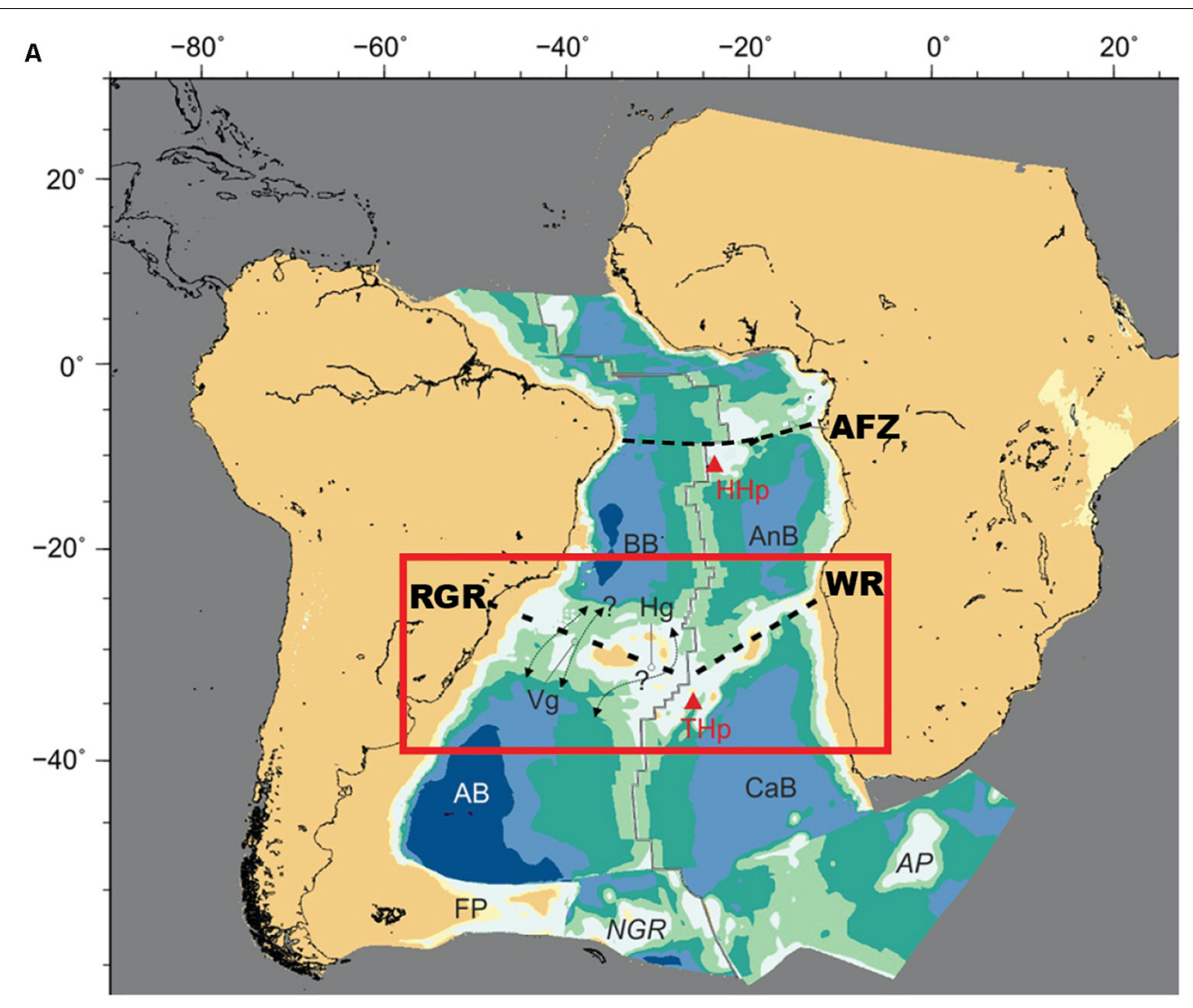

\section{B}

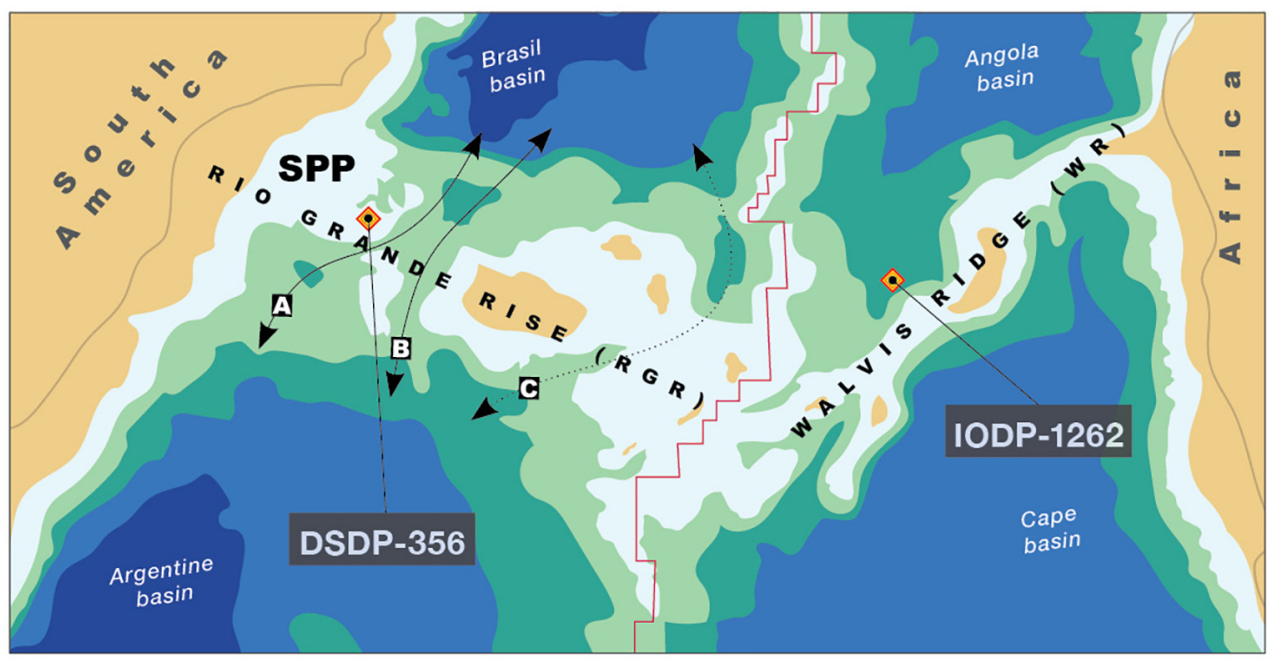

\section{Bathymetric} scale $(\mathrm{m})$

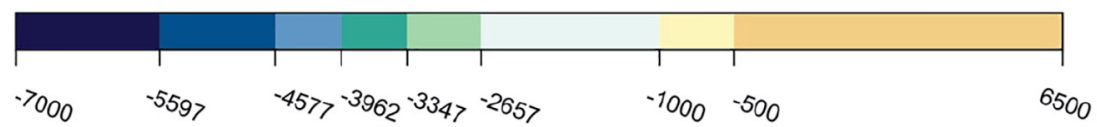

FIGURE 1 | Location of the Sao Paulo Plateau drill core [Deep-Sea Drilling Project (DSDP) Site 356] in the general paleogeographic context of the South Atlantic (A), after Pérez-Díaz and Eagles (2017). Brazil Basin (BB) and Angola Basin (AnB) are bordered North by the Ascension Fracture Zone (AFZ) and South by the Rio Grande (RGR) - Walvis Ridge (WR) zone. South of this obstacle lay the Argentine Basin (AB), Cape Basin (CaB) and further toward the south the Falkland Plateau (FP), North Georgia Rise (NGR) and the Agulhas Plateau (AP) Red triangles represent hotspots: St Helena (HHp) and Tristan da Cunha (THp). (B) detail view of the drill core's location, in the proximity of the Vema Gap (a,b) and Hunter Gap (c), the main oceanic passages across the Rio Grande Rise - Walvis Ridge system. Marked is also the International Ocean Discovery Program (IODP) Site 1262, discussed in the text. 
the Turonian-Maastrichtian interval; Wanderley and Pedrosa (2017), who improved the nannoplankton zonations in the Paleocene of the core; or Krahl et al. (2017) who refined planktic foraminifera zonation in the Paleocene. The research listed above provides the biostratigraphic controls for our magnetobio-stratigraphic age model. Other studies include work on Paleocene coccolithophores by Mai et al. (1998); the study on ostracodes from Sites 356 and 357 by Supko and Perch-Nielsen (1977), and geochemical investigations concerning the Oceanic Anoxic Event 3 (OAE3) levels of upper Cretaceous age (Herbin et al., 1987; Arai, 1988; Wagreich, 2012). These contain valuable paleoenvironmental information and are taken into account in the reconstruction of the evolution of the São Paulo Plateau. Our results from Site 356 contribute to a broader picture which is of interest across many different fields of research, such as the breakup of Gondwanaland (Avilla et al., 2002; Cogne et al., 2012), the formation of Cretaceous evaporites (Koutsoukos, 1992; Tedeschi et al., 2017; Silva et al., 2020), pre-salt oil reservoirs and source rocks (Buckley et al., 2015; Pietzsch et al., 2018; de Oliveira et al., 2019) and post-salt deformation processes (Guardado et al., 1989; Mohriak, 2003; Mohriak et al., 2008; Davison et al., 2012).

\section{LITHOLOGICAL DESCRIPTION}

The sedimentary record drilled in Site 356 has been divided into seven individual Units (Perch-Nielsen et al., 1977), starting with Albian pelagic sediments (unit 7) with significant contributions from nanoplankton and fine-grained terrigenous input (Thiede, 1977), followed by coarse clastic Coniacian - Mid Turonian mudstones and clay-pebble conglomerates (unit 6). The clastic unit is characterized by breccias and conglomerates with calcareous mudstone, zeolitic siltstone, ferruginous mudstone, and basalt pebbles and cobbles. The coarse unit is overlain by fine-grained sediments that range from marly calcareous chalks (unit 5), nanno and nanno-foram chalks (unit 4); silicified calcareous chalks (unit 3); calcareous- siliceous and siliceouscalcareous oozes (unit 2) and calcareous oozes (unit 1). The postConiacian (Late Cretaceous sediments) were deposited under oxic conditions in shallow waters and are expressed as relatively pure nannofossil and foraminiferal chalk, which continue into the upper Paleocene.

We focus on the 420-220 m bsf interval (Cores 30-11), corresponding to units 4 and 3 (uppermost Maastrichtian Lutetian) (Perch-Nielsen et al., 1977; Figure 2). Unit 4 corresponds to the upper Cretaceous - Paleogene interval and contains well bedded and moderately burrowed alternation of chalks (10-100 cm thick) and oozes (max. $100 \mathrm{~cm}$ thick). The lowermost part of the sequence is represented by monotonous gray chalks of upper Maastrichtian age, that grade into white mottled chalks just before the $\mathrm{K} / \mathrm{Pg}$ boundary. Following in the succession, the Danian is expressed by a 50 -meter-thick section of calcareous ooze (Figure 2). While the sequence is fairly homogeneous, environmental changes are reflected in the color of the sediment (brown, red and green levels) and associated minor compositional changes (Thiede, 1977). However, this work does not rely on these changes in coloration, in the investigation of environmental changes during the Danian. Selandian sediments consist of gray-dark gray chalks and contain two slump levels. A large slump is found at the base of the Selandian $(364 \mathrm{~m})$, comprising several large olistostromes $(0.84 \mathrm{~m})$ of middle-early Maastrichtian age. A smaller slump is found in the upper Selandian, at $319.5 \mathrm{~m}$, containing olistostromes of early Maastrichtian - Campanian age and suggesting that a nearby part of the plateau was undergoing erosion and experienced periods of significant slope instability in the Selandian. Unit 3 corresponds to the Eocene part of the section and consists of alternating chalks (bands of $10 \mathrm{~cm}$ to $1 \mathrm{~m}$ thickness) and oozes (up to $1 \mathrm{~m}$ thick sections) of light greenish-gray color (Perch-Nielsen et al., 1977).

Biostratigraphic studies have confirmed the existence of sedimentation gaps in the uppermost Maastrichtian - Lutetian interval, either very short, such as a missing (P0) foram zone $(\sim 100 \mathrm{kyr})$ at the Cretaceous- Paleogene boundary (Krahl et al., 2017), or large gaps (up to $\sim 7 \mathrm{Myr}$ ) from the Selandian/Thanetian boundary to mid-Ypresian (Perch-Nielsen et al., 1977). This study carefully considers the limitations posed by existing slump deposits. The main focus of this paper is the Danian-Selandian interval and the sedimentation rate changes during that period, with the uppermost Maastrichtian and the Ypresian-Lutetian serving as references for pre- and post- early Paleogene sedimentary environments.

\section{MATERIALS AND METHODS}

Natural remanent magnetization (NRM) was measured to compute the characteristic remanent magnetization (ChRM) and build a polarity sequence to correlate with the Geomagnetic Polarity Time Scale (GPTS). This was used to build an age model and calculate sedimentation rates. Later, a set of detailed environmental magnetism experiments (magnetic susceptibility, anhysteretic and isothermal remanent magnetizations, first-order reversal curve diagrams, Curie balance tests) were performed to characterize the sedimentary succession. Using our novel age model, we were able to correlate our obtained results with adjacent sites and discuss the implications.

\section{Demagnetization Protocol and Construction of Magnetostratigraphic Age Model}

Natural remanent magnetization is the remanent magnetization of a rock or sediment. It consists of a primary component - the ChRM, acquired during the formation of the rock or sediment, and often additional overlapping secondary components of later acquired magnetizations. Alternating field demagnetization (AF) technique is employed to isolate the primary component. It involves exposing the sample to a well-symmetrical alternating field that linearly decreases to zero in a magnetically shielded, null-field, environment. Multiple alternating field steps are used to completely demagnetize the specimen. This way, the secondary components may be removed, allowing us to identify the ChRM and reconstruct the magnetic field at the time of the formation of the sample. The stack of remanent magnetization results is 


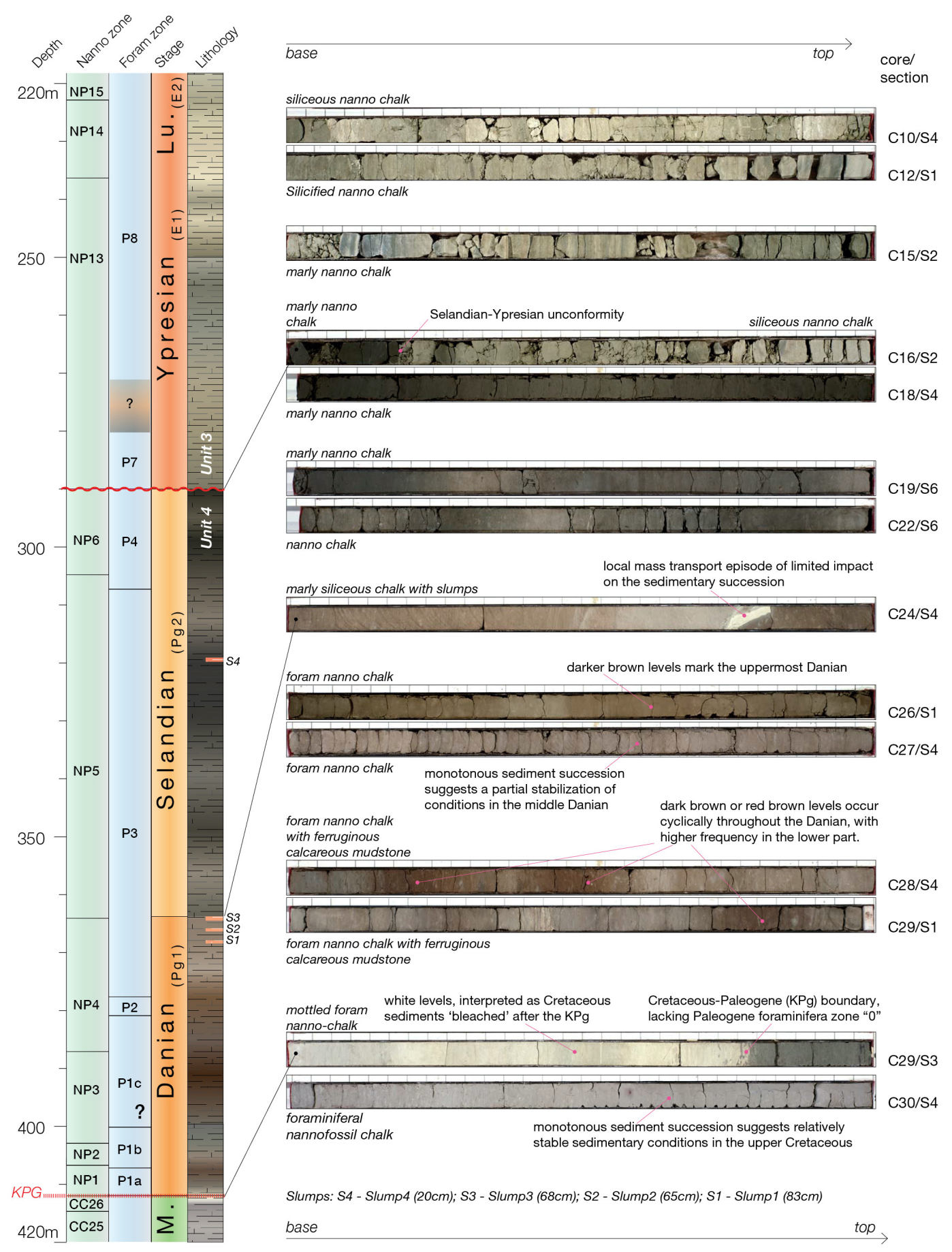

FIGURE 2 | Biostratigraphic zonation and lithological characteristics of the Paleogene succession at the Deep-Sea Drilling Project (DSDP) Site 356, with a selection of images representative for the sedimentary succession, taken during DSDP Leg 39 and their corresponding initial descriptions (in italics) (Perch-Nielsen et al., 1977), with added observations. Pink markers in Unit 4 (S1-S4) indicate intervals where slumps have been described.

plotted for each specimen and interpreted to extract the ChRM and corresponding paleomagnetic inclination value.

From Site 356 of DSDP Leg 39, a total of 297 oriented half core samples were requested from IODP (sample requests: 037143IODP and 071140-IODP). They were collected at MARUM
(Bremen, Germany) and transported to the University of São Paulo, where they were subsequently cut into $7-\mathrm{cm}^{3}$-cubes to be used for magneto-chronology, rock, and environmental magnetism experiments. The specimens were split into two sets and measured in São Paulo (Brazil) $(n=220)$ and in 
Utrecht (Netherlands) $(n=77)$. Paleomagnetic measurements were performed at Instituto de Astronomia, Geofísica e Ciências Atmosféricas of the University of São Paulo (USPMAG) in a magnetically shielded room with an ambient field of $<200$ nT. Stepwise alternating field demagnetization (AF) procedure was performed in a RAPID system $2 \mathrm{G}$ Enterprises DC SQUID cryogenic magnetometer (noise level $5 \times 10-12 \mathrm{Am}^{2}$ ) in vertical position, with a built-in coil system (Kirschvink et al., 2008). AF demagnetization was achieved by applying increasing alternating field steps up to $100 \mathrm{mT}$, with increments of $2.5 \mathrm{mT}$ for the $0-15$ $\mathrm{mT}$ interval and increments of $5 \mathrm{mT}$ for the 15-100 $\mathrm{mT}$ interval.

Another set of samples was demagnetized and measured for cross-comparison at Fort Hoofddijk Paleomagnetic Laboratory, Utrecht University. Alternating field demagnetization was performed up to a maximum of $250 \mathrm{mT}$, with field increments of $5 \mathrm{mT}$ for the $050 \mathrm{mT}$ interval, $10 \mathrm{mT}$ for the $50100 \mathrm{mT}$ interval, $20 \mathrm{mT}$ for the $100160 \mathrm{mT}$ interval and two supplementary steps of 200 and $250 \mathrm{mT}$ on a robotized horizontal 2G Enterprises DC SQUID cryogenic magnetometer (noise level of $3 \times 10^{-12} \mathrm{Am} 2$ ) (Mullender et al., 2016). Results from the demagnetization experiments were processed using principal component analysis (Kirschvink, 1980) implemented in Remasoft 3.1 paleomagnetic data analyzer software (Chadima and Hrouda, 2006).

\section{Rock Magnetic Measurements}

To characterize the magnetic properties of the sediments, a series of rock magnetic experiments were carried out. Anhysteretic remanent magnetization (ARM) and isothermal remanent magnetization (IRM) were measured at USPMAG after the demagnetization procedure. An axial ARM was imparted using a peak alternating field of $100 \mathrm{mT}$ with a bias DC field of $0.05 \mathrm{mT}$. For the IRM measurements, a pulsed field of $1 \mathrm{~T}$ was applied to the samples to obtain the saturation isothermal remanent magnetization (SIRM). Subsequently, a backfield of 0.3 $T$ was applied and measured. The data were then used to calculate the S-ratio (Bloemendal et al., 1992) and $\mathrm{K}_{A R M}$, representing ARM intensity divided by the bias field value to become a field-independent parameter, referred to as anhysteretic ARM susceptibility (due to its analogy with the low-field susceptibility) (Moskowitz, 2007).

Magnetic susceptibility was measured at the Centro Oceanográfico de Registros Estratigráficos (CORE) at the Oceanographic Institute of the University of São Paulo (IO USP) using an AGICO MFK1-KA Kappabridge (sensitivity $1 \times 10-8 \mathrm{SI})$ at the operating frequency of $976 \mathrm{~Hz}$ and applied field of $200 \mathrm{~A} / \mathrm{m}$. A subset of samples $(n=17)$ were selected for detailed rock magnetic characterization using a Vibrating Sample Magnetometer (VSM) Micromag 3900 Princeton-Lakeshore Cryotronics at IO USP. First Order Reversal Curves (FORC) were acquired for each of the samples and processed in the FORCinel software package (Harrison and Feinberg, 2008) using VARIFORC smoothing (Egli, 2013).

Thermomagnetic measurements of the induced magnetization (J-T curves) were conducted with a modified horizontal translation-type Curie balance with a drift of $\sim 5 \times 10-9$ Am 2 at Fort Hoofddijk (Mullender et al., 1993). A field cycled between 100 and $300 \mathrm{mT}$ was applied to powdered sediments ( 70 mg).
Multiple heating runs (at a heating rate of $6^{\circ} \mathrm{C} / \mathrm{min}$ ) and cooling runs (at a cooling rate of $10^{\circ} \mathrm{C} / \mathrm{min}$ ) were performed between room temperature and steps of $150^{\circ}, 250^{\circ}, 350^{\circ}, 450^{\circ}$, $525^{\circ}$, and $700^{\circ} \mathrm{C}$.

\section{RESULTS}

\section{Demagnetization Results}

We obtained ChRM directions for 297 samples of both reversed and normal polarities. The demagnetization diagrams (Figure 3) reveal different types of magnetic behavior. In some samples, a weak, viscous overprint, without coherent directions, is present, generally removed by $15 \mathrm{mT}$. A second component that we consider the ChRM is demagnetized at fields between 15 and $45 \mathrm{mT}$, accounting for $30-70 \%$ of the sample intensity. A limited subset of 17 discrete samples develop a third type of behavior at fields above $45 \mathrm{mT}$, described as an unusual "NRM curlingup" (Fu et al., 2008) during AF demagnetization, associated with an increase of magnetization. Such behavior has been generally associated with a laboratory-induced gyroremanent magnetization (GRM) effect, which is characteristic of greigite (Snowball, 1997). The ChRM component was calculated from four or more consecutive field steps between 15 and $45 \mathrm{mT}$, using principal component analysis (Kirschvink, 1980). In order to provide a better understanding of the ChRM obtained, the data were grouped into two qualitative categories:

(1) Q1; high-quality directions, representing samples with a maximum angular deviation (MAD) up to $7^{\circ}$ (Figure 4 , black dots), and

(2) Q2; low-quality directions, comprising samples with abnormal orientations that do not demagnetize, deflect from a direction toward the origin, or have a MAD higher than $7^{\circ}$ (Figure 4, white dots). We adopted the highquality results from samples in the first group $(n=182$, representing $60.67 \%$ of total samples) in the development of the polarity pattern for the section. Samples in the latter category ( $n=118$, representing the remaining $39.33 \%$ of the samples) were discarded and not used in the determination of polarity, but have been calculated and plotted to highlight areas where the ChRM is poorly preserved. Results obtained from the late Cretaceous-Eocene record from the São Paulo Plateau comprises 15 polarity intervals, seven normal and eight reversed (Figure 4).

The average magnetic inclination for the samples in group Q1 is $23.1^{\circ}$. We use the E-I method (Tauxe et al., 2008) on the online platform Paleomagnetism.org to detect and correct for inclination shallowing on directions of the São Paulo samples. After unflattening (Supplementary Figure S1), the average inclination changes from to $29.94^{\circ}$ (after unflattening).

\section{Magnetic Properties of Sediments at Site 356}

The variation in low-field magnetic susceptibility is reflected in the magnetic mineralogy of the sample. Figure $5 \mathbf{E}$ shows 


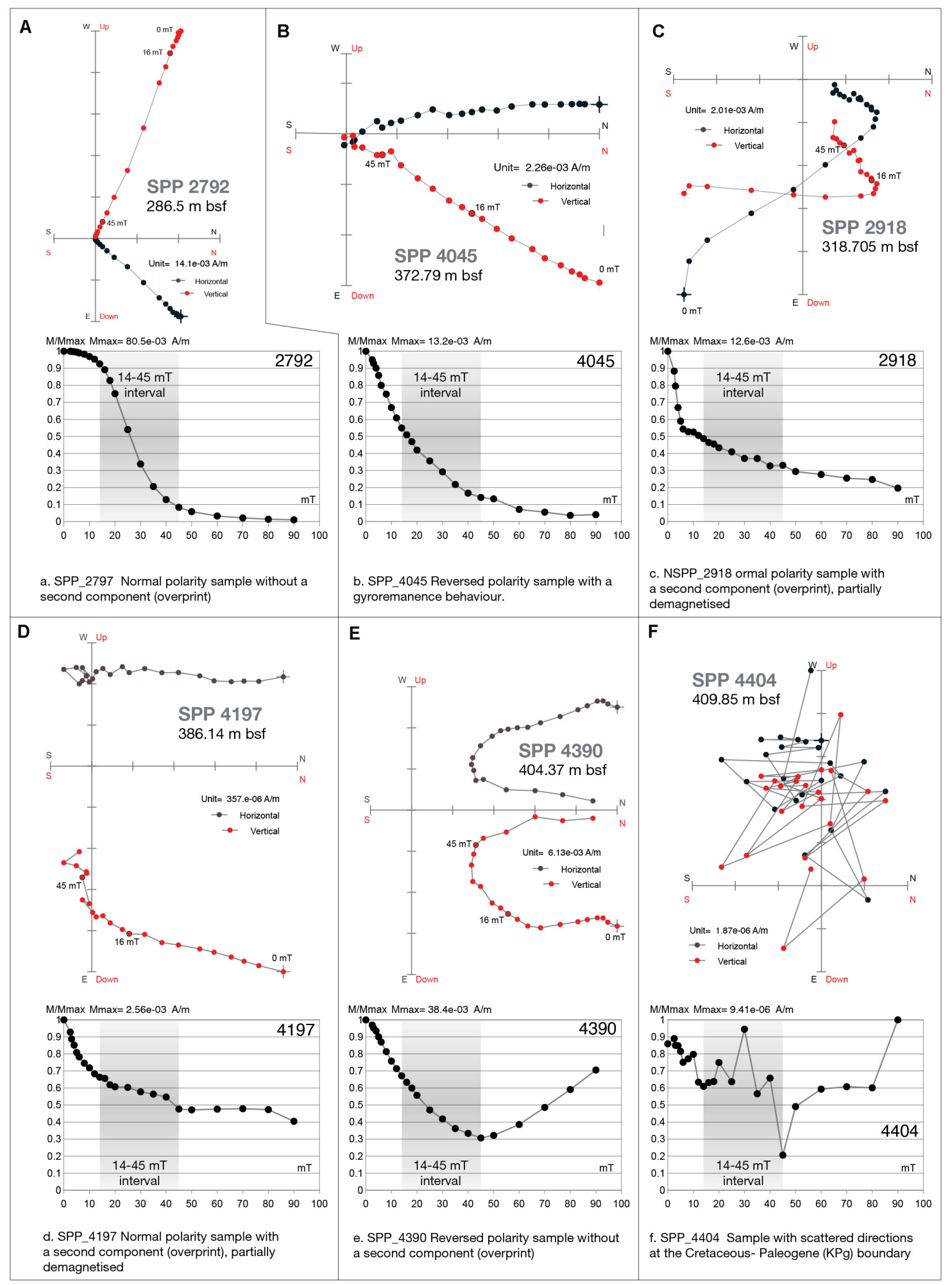

FIGURE 3 | Key types of magnetic behavior illustrated with Zijderveld diagrams and magnetic intensity plots. Samples (A-C) are considered reliable NRM carriers due to their stable directions during the demagnetization process, while samples (D-F). are examples of problematic demagnetization: sample (D) does not demagnetize, sample (E) acquires a magnetic field in the course of demagnetization and sample (F) exhibits an erratic behavior during demagnetization. 


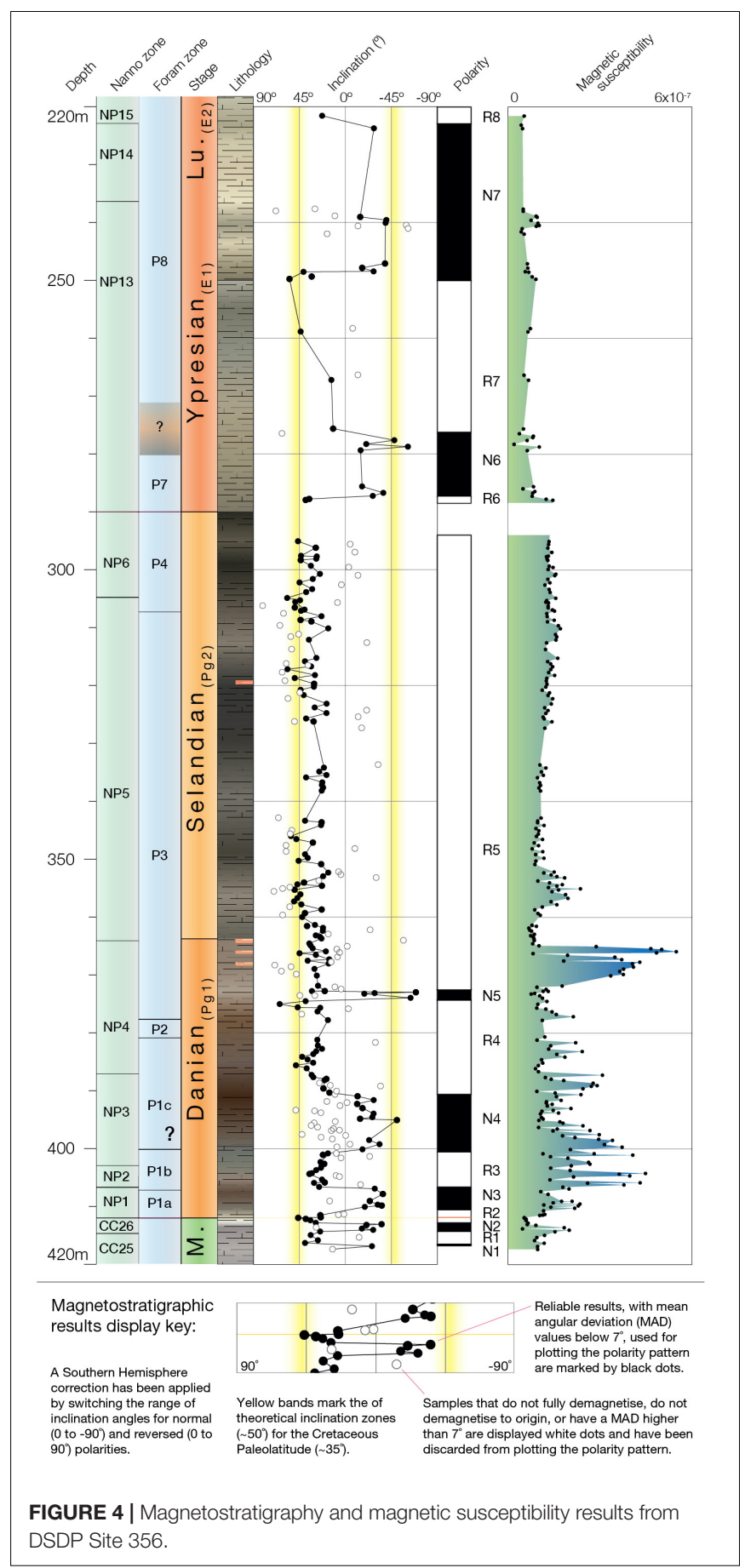

a plot of volumetric susceptibility $(\kappa)$ vs. the susceptibility of ARM ( $\mathrm{ARM}$ ), often used as a magnetic grain size proxy. While $\kappa$ is a measure of the concentration of magnetic material within a sample, most sensitive to superparamagnetic (SP) grains $(<0.03 \mu \mathrm{m})$ and large grains $(<10 \mu \mathrm{m}), \kappa A R M$ is strongly grainsize dependent, exhibiting highest values for the finest particles (Opdyke and Channell, 1996; Hillaire-Marcel and De Vernal, 2007). The properties are quite varied within the core, with Danian samples having the highest concentration of particles within the single-domain (SD) grain size range, considered ideal magnetic recorders. This is supported by FORC diagram signatures. Sample 4017 has a central ridge with a moderate degree of vertical spread indicative of slightly interacting SD grains, with peak coercivities at $\sim 40 \mathrm{mT}$ (Egli, 2013). On the other hand, the lowest concentration and largest grain sizes are shown by Eocene samples. The FORCs show low coercivities below $20 \mathrm{mT}$. Samples 4197 and 3946 have intermediate values in the scatter plot, their FORC signatures showing overlapping features of a low coercivity central ridge suggesting an SD component, and a high coercivity lobe extending up to $200 \mathrm{mT}$. These kinds of high coercivity features can be indicative of hematite (Carvallo et al., 2006; Roberts et al., 2006). The downcore variations of the measured rock magnetic proxies are shown in Figure 6 alongside stable isotope measurements from the nearby Walvis Ridge (Kochhann et al., 2014). In the Danian and partially the Selandian stages, the S-Ratio shows high variability, indicating a changing composition of low and high coercivity minerals. The high coercivity is most likely due to the presence of hematite, as indicated by the FORCs.

The thermal runs on the Curie balance indicate the presence of at least two different magnetic minerals. Samples such as 3866 are characterized by thermally stable magnetic carriers, indicated by the reversible behavior during the intermediate heating-cooling cycles $\left(150^{\circ}, 250^{\circ}, 350^{\circ}, 450^{\circ}, 525^{\circ} \mathrm{C}\right)$. The Curie temperature of $\sim 580^{\circ} \mathrm{C}(853 \mathrm{~K})$ is indicative of stoichiometric magnetite (Gehring et al., 2009), but the curved nature of the heating curve (Figure 5), indicates a contribution from a paramagnetic clay minerals component (Opdyke and Channell, 1996). Sample 4404 is representative of samples with stronger magnetic intensity. It has a thermally unstable component, indicated by irreversible behavior with a loss of magnetic intensity at each of the intermediate heating-cooling steps, indicated by the gray dotted lines (Figure 5), and a thermally stable component (marked with orange dotted lines) characterized by slightly higher unblocking temperature at $\sim 630^{\circ} \mathrm{C}$. This is close to the thermal ranges attributed to maghemite (890 K) (Gehring et al., 2009). In our case, the behavior fits type $\mathrm{C}$ maghemite as described by Liu et al. (2010) - a partially thermally reversible carrier with a measurable Curie temperature of $640^{\circ} \mathrm{C}$ (Ozdemir and Banerjee, 1984).

As maghemite is formed by weathering or low-temperature oxidation of spinels containing ferrous iron, commonly magnetite (Gehring et al., 2009), it is possible specimens exhibiting this behavior correspond to levels of magnetite oxidation (Chang et al., 2013). The magnetic mineralogy of the core comprises multiple magnetic minerals present in different grain sizes. Nonetheless, all of them have the potential to preserve a stable magnetic signal through geologic time and do not show signs of pervasive remagnetization or alteration.

\section{Magneto-Bio-Stratigraphy}

We use an integrated magneto-bio-stratigraphic approach to correlate the Sao Paulo Plateau record with the geomagnetic polarity time scale (GPTS). A selected set of foraminifera and nannoplankton zones and sub-zone boundaries derived from previous studies on Site 356 were used as tie-points in the age-depth correlation (Table 1). As a global reference, we 
A

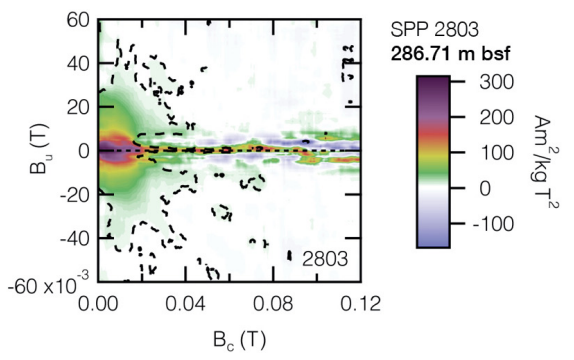

B

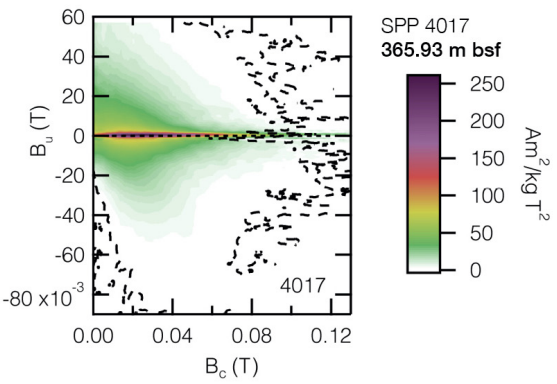

C

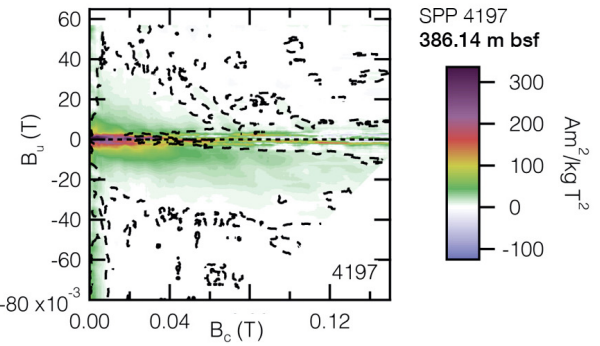

F

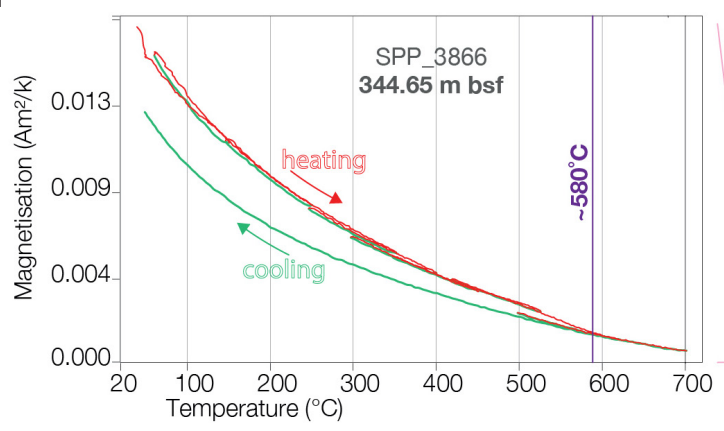

D
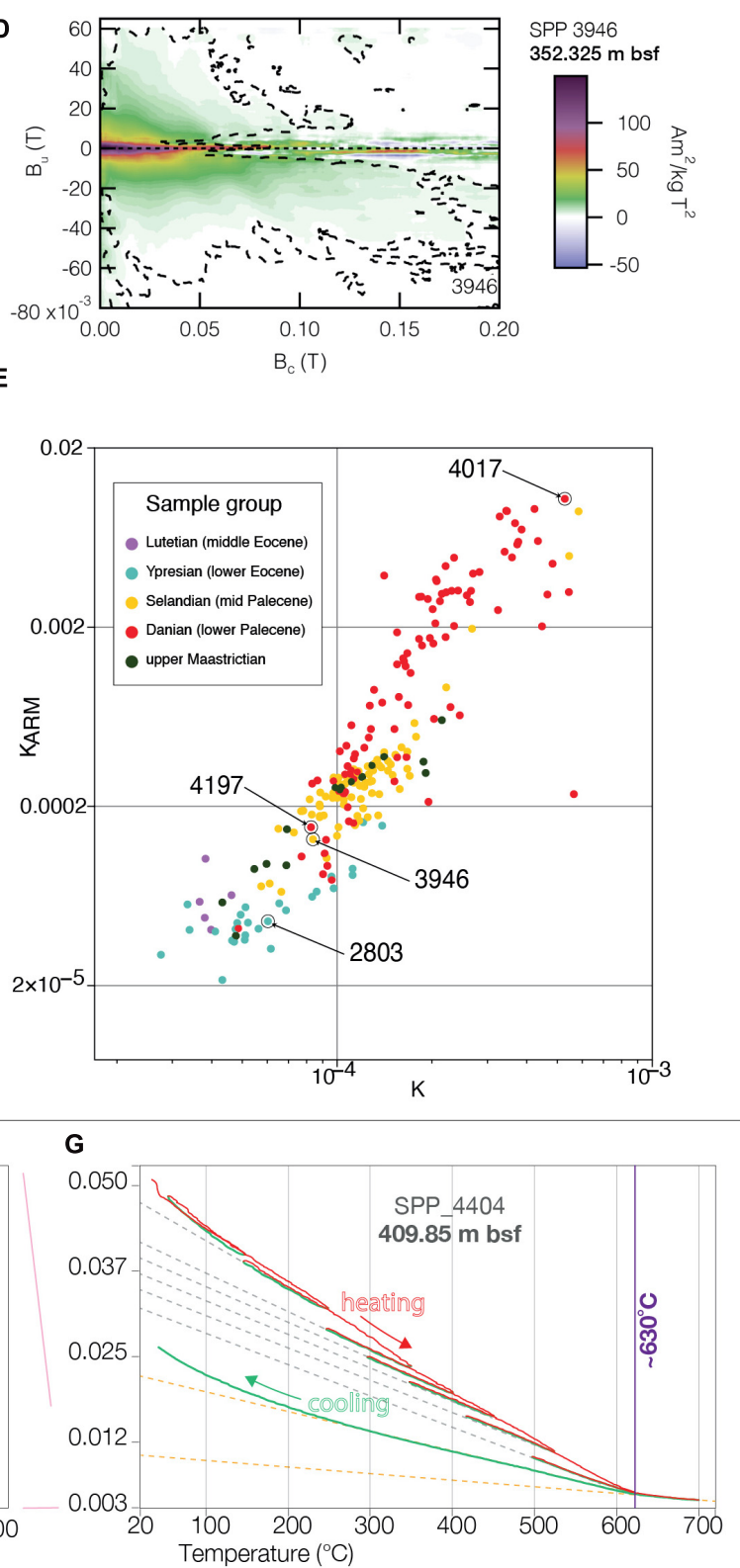

FIGURE 5 | Rock magnetic characterization of Site 356. (A-D) Selected First order reversal curve (FORC) diagrams from different stages: (A) Ypresian (2803), (B,C) Danian (4017, 4197) (D) Selandian (3946); (E) KARM/K plot (Banerjee et al., 1981; King et al., 1982) with marked locations of FORC diagrams; (F-G) Results of thermal experiments using a Curie Balance, for samples 3866 (Selandian) and 4404 (Danian). Purple lines indicate unblocking temperatures. Gray dotted lines represent the projected cooling curves at a given step. See text for interpretation.

use the TSCreator visualization of enhanced Geologic Time Scale 2016 database (Version 7.4; 2020) (Gradstein and Ogg, 2006), calibrated with the concise Geologic Time Scale 2016 (Ogg et al., 2016).

By cross-plotting the Paleogene nannozone boundaries from our section and the GPTS (Figure 7), we identify several reference chron's that can be attributed to polarity zones of the GPTS (Table 2). Several polarity zones in the record lack sufficient data points for a robust correlation with the GPTS. In the case of zone $\mathrm{N} 1$, the obtained dataset has too few points to confidently be attributed to a normal polarity zone, and we refrain from doing so at this stage. The normal polarity zone N7 corresponds to nannoplankton zones NP13 and NP14, in contradiction with the GPTS, where a reverse polarity zone would be expected at the NP13/NP14 boundary. We consider that the interval corresponding to the reverse polarity zone is missing. Based on nannoplankton data, we subsequently split N7 in two zones, N7a corresponding to upper Ypresian, and N7b that corresponds to Lutetian, but lacking more data points, we refrain from further correlations. The following interval (R8) would 


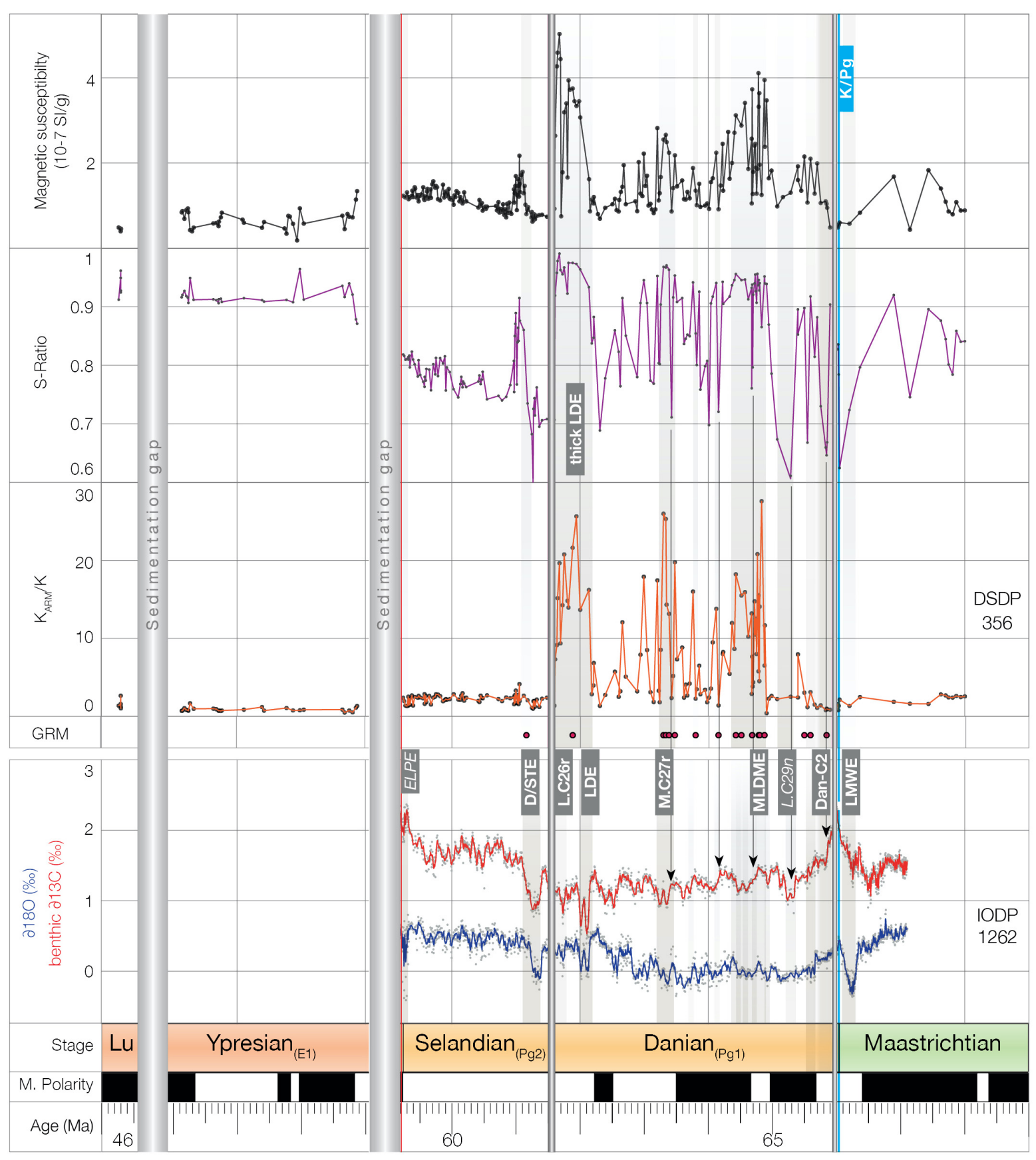

FIGURE 6 | Stratigraphic correlations of Site 356 with global events. From the top: magnetic susceptibility and S-ratio for Deep Sea Drilling Program (DSDP) Site 356 obtained in this study, stage and magnetic polarity, and benthic $\delta^{13} \mathrm{C}$ from Barnet et al. (2019). Marked are the major recognized events reported in the literature discussed in the text: the Cretaceous-Paleogene boundary (blue) and suspected hyperthermal-like events (red): the Cretaceous-Paleogene boundary (K/Pg), the Dan-C2 event (Dinarès-Turell et al., 2014; Jehle et al., 2015), L.C29n (Barnet et al., 2019), M.27Cr (Barnet et al., 2019), Late Danian Events (LDEs) LDE1 and LDE2 (Sprong et al., 2012; Jehle et al., 2015; Deprez et al., 2017), L.C26r (Barnet et al., 2019), Danian/Selandian Transition Event (D/STE) (Arenillas et al., 2008), Early-Late Paleocene Event (ELPE) (Coccioni et al., 2019).

belong to Lutetian as well, but given limited data points remains difficult to correlate. These intervals have been excluded from further interpretation, such as sedimentation rates calculations or age model development. We obtain 11 tie-points based on the magneto-stratigraphic correlation that can be used for developing an age model for the section (Table 2).

Using the newly obtained magnetostratigraphic tie-points and biostratigraphic zone boundaries (nannoplankton tie points) we 
TABLE 1 | Tie-points from previous studies used for the development of the age model for Site 356 in this study.

\begin{tabular}{|c|c|c|c|c|c|c|}
\hline $\mathrm{Nr}$ & Site 356 Polarity zone & Event & CODE & Depth (mbsf) & Age (Ma) & Biblographic refference \\
\hline 1 & NP15/NP14 & boundary & Nanno & 222.345 & 46.29 & Perch-Nielsen et al., 1977 \\
\hline 2 & NP14/NP13 & boundary & Nanno & 238.4275 & 49.11 & Perch-Nielsen et al., 1977 \\
\hline 3 & $E L P E$ & event & CIE & 295 & 59.24 & Barnet et al., 2019 \\
\hline 4 & NP6/NP5 & boundary & Nanno & 304.365 & 59.54 & Perch-Nielsen et al., 1977 \\
\hline 5 & $\mathrm{P} 4 / \mathrm{P3}$ & boundary & Foraminifera & 314.35 & 60.73 & Gradstein and Ogg, 2006 \\
\hline 6 & $\mathrm{P} 3 \mathrm{a} / \mathrm{b}$ & boundary & Foraminifera & 363.24 & 61.3 & Krahl et al., 2017 \\
\hline 7 & NP5/NP4 & boundary & Nanno & 364.735 & 61.51 & Perch-Nielsen et al., 1977 \\
\hline 8 & P3/P2 & boundary & Foraminifera & 377.24 & 62.297 & Gradstein and Ogg, 2006 \\
\hline 9 & $\mathrm{P} 2 / \mathrm{P} 1$ & boundary & Foraminifera & 385.24 & 62.597 & Gradstein and Ogg, 2006 \\
\hline 10 & NP4/NP3 & boundary & Nanno & 388.08 & 63.25 & Perch-Nielsen et al., 1977 \\
\hline 11 & $\mathrm{P} 1 \mathrm{c} / \mathrm{b}$ & boundary & Foraminifera & 391.77 & $x$ & Krahl et al., 2017 \\
\hline 12 & $\mathrm{P} 1 \mathrm{~b} / \mathrm{a}$ & boundary & Foraminifera & 402.77 & x & Krahl et al., 2017 \\
\hline 13 & NP3/NP2 & boundary & Nanno & 405.1 & 64.81 & Perch-Nielsen et al., 1977 \\
\hline 14 & $\mathrm{P} 1 / \mathrm{P} \alpha$ & boundary & Foraminifera & 409.25 & 65.719 & Krahl et al., 2017 \\
\hline 15 & NP2/NP1 & boundary & Nanno & 409.43 & 65.47 & Perch-Nielsen et al., 1977 \\
\hline 16 & $K P G$ & boundary & event & 411.75 & 66.063 & Gradstein and Ogg, 2006 \\
\hline 17 & CC25/CC26 & boundary & Nanno & 416.0725 & 67.84 & Perch-Nielsen et al., 1977 \\
\hline 18 & Racemiguembelina fructicosa & LO & Foraminifera & 412.25 & 66.4 & Kochhann et al., 2014 \\
\hline 19 & Abathomphalus mayaroensis & LO & Foraminifera & 415.25 & 66.35 & Kochhann et al., 2014 \\
\hline 20 & Gasserina gansseri & LO & Foraminifera & 415.25 & 66.49 & Kochhann et al., 2014 \\
\hline 21 & Pseudoguembelina hariaensis & $\mathrm{FO}$ & Foraminifera & 440.67 & 67.3 & Kochhann et al., 2014 \\
\hline 22 & Globotruncana linneiana & LO & Foraminifera & 445.16 & 68.37 & Kochhann et al., 2014 \\
\hline 23 & Abathomphalus mayaroensis & FO & Foraminifera & 443.51 & 69.18 & Kochhann et al., 2014 \\
\hline 24 & Racemiguembelina fructicosa & $\mathrm{FO}$ & Foraminifera & 443.51 & 70.14 & Kochhann et al., 2014 \\
\hline 25 & Pseudoguembelina palpebra & $\mathrm{FO}$ & Foraminifera & 462.83 & 71.75 & Kochhann et al., 2014 \\
\hline 26 & Gasserina gansseri & $\mathrm{FO}$ & Foraminifera & 459.78 & 72.97 & Kochhann et al., 2014 \\
\hline 27 & Globotruncana aegyptiaca & $\mathrm{FO}$ & Foraminifera & 462.83 & 74 & Kochhann et al., 2014 \\
\hline 28 & Radotruncana calcarata & LO & Foraminifera & 485.27 & 75.71 & Kochhann et al., 2014 \\
\hline 29 & Globotruncanella havanensis & $\mathrm{FO}$ & Foraminifera & 464.32 & 75.94 & Kochhann et al., 2014 \\
\hline 30 & Radotruncana calcarata & $\mathrm{FO}$ & Foraminifera & 489.77 & 76.18 & Kochhann et al., 2014 \\
\hline 31 & Contusotruncana plummerae & FO & Foraminifera & 518.27 & 79.2 & Kochhann et al., 2014 \\
\hline 32 & Globotruncanita elevata & $\mathrm{FO}$ & Foraminifera & 545.27 & 83.64 & Kochhann et al., 2014 \\
\hline 33 & Dicarinella asymetrica & LO & Foraminifera & 542.27 & 83.64 & Kochhann et al., 2014 \\
\hline 34 & Dicarinella concavata & LO & Foraminifera & 542.27 & 83.64 & Kochhann et al., 2014 \\
\hline 35 & Dicarinella asymetrica & $\mathrm{FO}$ & Foraminifera & 649.77 & 86.66 & Kochhann et al., 2014 \\
\hline 36 & Dicarinella concavata & $\mathrm{FO}$ & Foraminifera & 681.27 & 91.08 & Kochhann et al., 2014 \\
\hline
\end{tabular}

FO indicates first occurrences, LO last occurrences.

calculated the linear sedimentation rates (LSRs) and developed an age model which allows the attribution of an age to the depth levels of our samples, enabling correlations between Site 356 and other records on the planet.

\section{DISCUSSION}

\section{Magnetic Mineralogy and the Reliability of the Magnetostratigraphic Record}

The magnetic mineralogy of the core is complex, as highlighted by the scatter and variability of different magnetic behaviors apparent in the FORC diagrams, heating experiments, and modified Zijderveld plots (Zijderveld, 2013). This is perhaps not unexpected considering the varied lithology throughout the early Paleogene in the São Paulo Plateau. The conditions at the end of the Maastrichtian change drastically from a carbonate dominated regime into a ferruginous mudstone characterized by alternating shades of brown and red, prevalent throughout the Danian, as shown by S-ratio variability (Figure 6). The late Danian is marked by slumps and localized mass transport deposits. In the Selandian conditions begin to stabilize, which is reflected in a shift in the lithology, which becomes dominated by dark deposits of marly nannoplankton chalk with few disturbances of the sedimentary sequence. The change in sedimentation regime is reflected in the magnetic mineral composition, with the S-ratio settling at higher values $(\sim 0.75)$. Moving into the Eocene, the environment settles into calmer settings with less terrigenous input present in the light-colored silicious chalk. The shift between the different sedimentary regimes is reflected in the magnetic susceptibility curve (Figure 4). With the changing environmental conditions, 


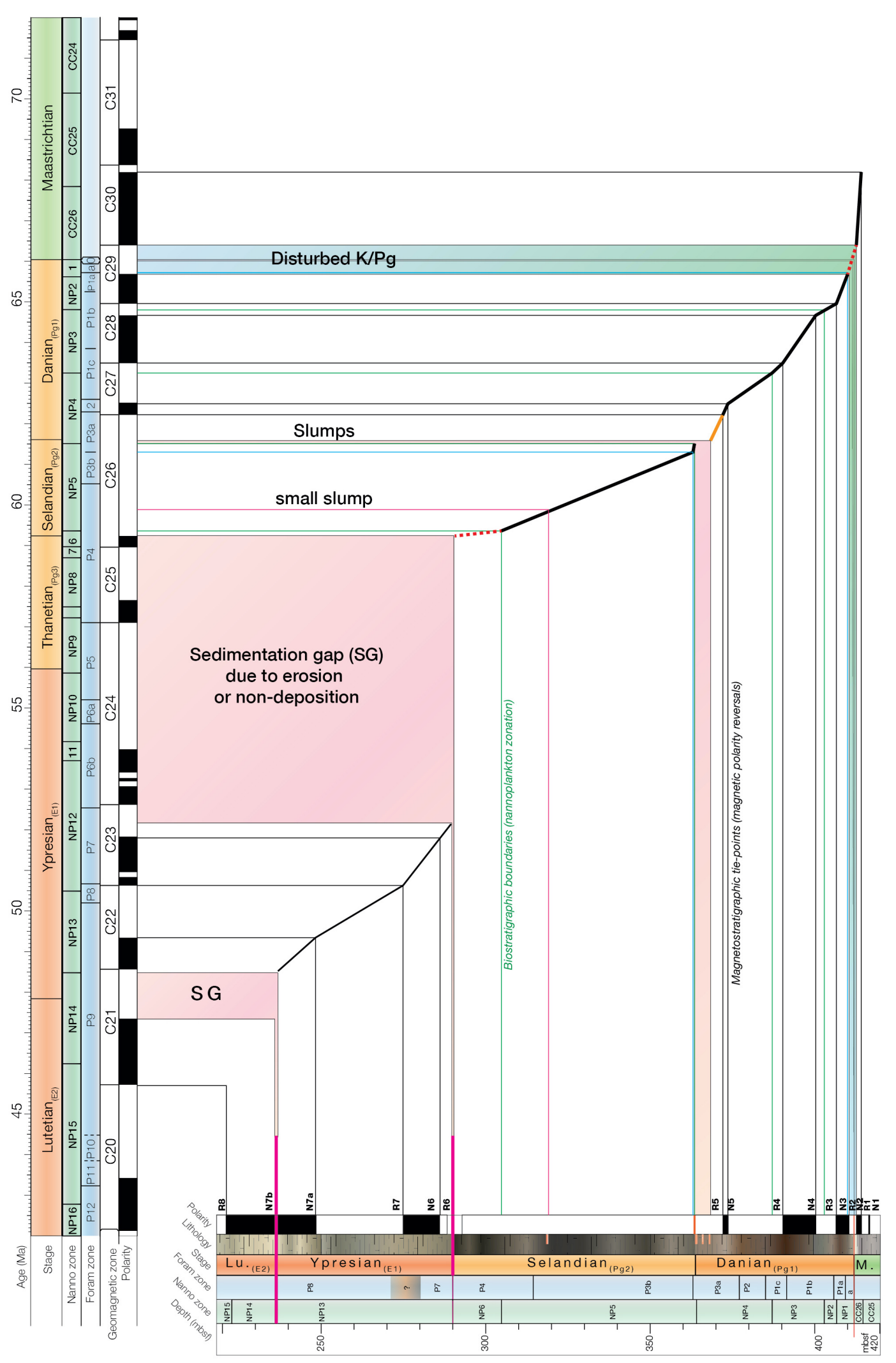

FIGURE 7 | Age model for Site 356 obtained by correlating the reversal pattern and biostratigraphic zonation from site 356 with the Geomagnetic Polarity Time Scale (GPTS 2012). Black lines magnetostratigraphic tie-points, while blue and green lines indicate biostratigraphic tie-points (based on foraminifera zones - blue, and nannoplankton zones - green). 
TABLE 2 | Magnetostratigraphic tie-points used in the age model for Site 356.

\begin{tabular}{|c|c|c|c|c|c|c|}
\hline $\mathrm{Nr}$ & Site 356 Polarity zone & Polaity & CODE & GPTS Correlation & Depth (mbsf) & Age of base (Ma) \\
\hline 1 & R8 & Reversed & & C2Or & 223.13 & $x$ \\
\hline 2 & N7B & Normal & & C21 & 238 & x \\
\hline 3 & N7A & Normal & & C22n & 248.49 & 49.714 \\
\hline 4 & $\mathrm{R} 7$ & Reversed & & C22.r & 276.65 & 50.778 \\
\hline 5 & N6 & Normal & & C23.n & 286.975 & 51.774 \\
\hline 6 & R6 & Reversed & & C23.r & 287.94 & $x$ \\
\hline 7 & $E L P E$ & $G A P$ & & ELPE & 295 & 59.24 \\
\hline 8 & R5 & Reversed & & $\mathrm{C} 26 \mathrm{r}$ & 372.895 & 62.221 \\
\hline 9 & N5 & Normal & & $\mathrm{C} 27 \mathrm{n}$ & 373.4 & 62.517 \\
\hline 10 & $\mathrm{R} 4$ & Reversed & & $\mathrm{C} 27 \mathrm{r}$ & 390.795 & 63.494 \\
\hline 11 & N4 & Normal & & C28n & 400.4825 & 64.667 \\
\hline 12 & R3 & Reversed & & C28r & 406.775 & 64.958 \\
\hline 13 & N3 & Normal & & C29n & 410.165 & 65.688 \\
\hline 14 & $K / P g$ & GAP & & $K / P g$ & 411.75 & 66.063 \\
\hline 15 & $\mathrm{R} 2$ & Reversed & & C29r & 412.95 & 66.052 \\
\hline 16 & N2 & Normal & & C30n & 414.19 & 67.61 \\
\hline 17 & $\mathrm{R} 1$ & Reversed & & C31r & 416.305 & $x$ \\
\hline 18 & N1 & Normal & & $x$ & & $x$ \\
\hline
\end{tabular}

Reference chron's have been attributed to polarity chron's of the GPTS.

the magnetic mineral composition changes. Iron oxides are highly sensitive to fluctuating bottom water oxygenation, and the changes in ocean circulation are reflected in magnetic mineral composition. The rapid rate of change is reflected in the sawtooth pattern, which characterizes the early Paleogene, suggestive of unstable bottom water conditions. In the early Paleogene, the alternating red-brown layers are dominated by hematite and biogenic magnetite, respectively (Figure 5). The Selandian seems to be somewhat transitional, with a contribution of both components. Hematite input diminishes by the Eocene, where the magnetic mineral assemblage seems to be dominated by weak low coercivity magnetite, highly dispersed in the carbonate matrix. Surprisingly, the hematite biogenic magnetite levels exhibit maghemite-like signatures during thermal runs (Sample 4404 in Figure 5), suggesting a complex iron oxide mix that is not present in the samples where the thermal runs picks up magnetite and paramagnetic clay minerals signals (Sample 3866).

It is challenging to resolve the origin of the magnetic minerals identified in this study, and it is not the primary focus of this study to discuss the environmental implications. The main concern for the reliability of the magnetostratigraphy and constructed age model is the lack of significant overprinting of the ChRM through secondary alteration processes. The presence of hematite, in particular in tectonically active regions such as the SPP, is often indicative of hydrothermal activity and magnetic overprinting (e.g., Ohmoto, 2003). In the case of Site 356, this seems not to be the case. In the context of the magnetostratigraphy and polarity patterns, samples with different magnetic mineral composition (hematite vs. magnetite dominated samples) do not plot outside the general trend. This indicates that the alternating mineralogy does not affect the ability of the samples to carry ChRM, and there is no evidence for a delayed, secondary acquisition of magnetization. This implies that the maghemite and hematite components are most likely primary in origin, rather than diagenetic or hydrothermal.

Nonetheless, some samples have clear magnetic overprints, evident in the Zijderveld diagrams. In particular, some exhibit gyroremanent-like behavior (Sample 4390 in Figure 3). Although most commonly associated with greigite-bearing sediments (e.g., Snowball, 1997). It is interesting to note that all the samples which show GRM like properties during the demagnetization plot within the anomalous Danian interval (red dots in Figure 6). Coinciding with peaks in $\mathrm{KARM}$, they cluster in intervals of high magnetic susceptibility and S-ratios approaching 1 . This indicates the predominance of SD magnetite in these intervals, in agreement with magnetite-maghemite Curie temperatures. Oxic conditions are at odds with the presence of greigite. Specimens which show gyroremanent behavior have polarities consistent with adjacent samples. The selected range of fields used for calculating the polarity pattern (low-medium fields) are not affected by gyroremanence. Despite the potential challenges in demagnetizing all samples completely, they carry significant information which is consistent with nearideal samples. We therefore consider the magnetostratigraphy highly reliable. An exception are samples at the CretaceousPaleogene boundary, which do not carry any significant paleomagnetic information (Sample 4404 in Figure 3). Low intensities and spiderweb type Zijderveld diagrams point toward the possible dissolution of magnetic minerals due to acidification of oceans, commonly reported at the $\mathrm{K} / \mathrm{Pg}$ (Hull et al., 2020). Another potential mechanism of loss of ChRM could be the physical disturbance of sediments as an immediate consequence of the impact. Evidence of such has not been reported at such southern latitudes to date to the best of our knowledge. To shed further light into the K/Pg interval, a high resolution geochemical and rock magnetic study would be required. 


\section{Sedimentary Anomalies and Trends Across the Paleogene}

Sedimentation rates and sedimentation anomalies can point to key changes in ocean circulations and sea-straits dynamics and have been observed in other regions of the planet such as near the Gibraltar straits, in the North Atlantic (e.g., HernándezMolina et al., 2014) or, on a larger scale, throughout the Southern Ocean (e.g., Dutkiewicz et al., 2016). -1562449187$1562449187 \mathrm{We}$ plot sedimentation anomalies, such as gaps or mass transport deposits extracted from direct core observations or seismics, that are more straightforward and provide an insight about moments of instability or change in the depositional regime of the basin together with the sedimentation-rates estimation, that can contribute with qualitative supplementary information.

Several sedimentation anomalies (Figure 8) have been reported from 356 (Perch-Nielsen et al., 1977). After the K/Pg, the section contains a small sedimentation gap $(\sim 100 \mathrm{kyr})$ evidenced by the missing $\mathrm{P}(0)$ nannoplankton zone. Another sedimentation anomaly, characterized by slumps and sedimentary gaps, occurred before the Danian-Selandian boundary and, according to the nanno- and foram sub-zones P3a and P3b boundaries (Kochhann et al., 2014), corresponds to a time window between the top of the LDE and the base of the Selandian stage. Smaller slumps have also been reported in the middle of the Selandian interval, while the largest sedimentation gap begins at $59 \mathrm{Ma}$, roughly corresponding with the onset of the Early Late Paleocene Event (ELPE), and lasts until $51 \mathrm{Ma}$ (Figure 8).

In addition to these anomalies, the sedimentation rates for the Paleogene, coupled with previous biostratigraphy based sedimentation rates for the Cretaceous of Kochhann et al. (2014) shows a big picture of sedimentation trends in this region of the Atlantic Ocean in the 50-90 Ma interval (Figure 8). During the Cretaceous, sedimentation rates in the São Paulo Plateau were relatively low and largely constant with two exceptions: (1) the Santonian, when sedimentation rates more than quadrupled, broadly coinciding with the Oceanic Anoxic Event 3 (OAE3) (Herbin et al., 1987; Wagreich, 2012); and (2) the latest Maastrichtian, when sedimentation rates increased again. The Danian appears to be characterized by an increase in sedimentation, interrupted by discrete short-lived anomalies, while the Selandian seems to be increased by higher sedimentation rates but the reduced chronological tie-points limits the interpretations for this interval.

The Danian contains a set of discrete intervals of either extremely high or extremely low sedimentation rates. We find that these are tied to the occurrence of well-known periods of rapid climate shifts, often reported as proposed hyperthermal events (Coccioni et al., 2012; Sprong et al., 2012; DinarèsTurell et al., 2014; Jehle et al., 2015; Deprez et al., 2017; Barnet et al., 2019).

\section{Evidence for a Changing Climate}

Although the study of early Paleogene Carbon Isotope Excursions (CIE) and hyperthermals are somewhat overshadowed by the more spectacular End-Cretaceous Chicxulub cataclysm and the subsequent Cretaceous-Paleogene Extinction event, robust work has been conducted to determine the amplitude and duration of these climatic anomalies in the early Paleogene time. Our understanding of early Paleogene climate anomalies is based on key reference sites such as Walvis ridge (Leg 208, in particular, Hole 1262) in the South Atlantic (Barnet et al., 2019), Shatsky Rise (in particular Hole 1209) in the Central Pacific (Westerhold et al., 2011), Zumaia (Spain) in the North Atlantic (Dinarès-Turell et al., 2014), Gubbio-Contessa (Italy) in the western Tethys (Coccioni et al., 2012, 2019; Sinnesael et al., 2016; Figure 9), North-Eastern Desert and Sinai region (Egypt) in the south Tethys (Schulte et al., 2013), Boltysh crater lake (Ukraine) continental Eurasia in north Tethys (Gilmour et al., 2014) and Wombat plateau (IODP Leg 122, Hole 761) in the Indian Ocean (Quillevere et al., 2002). A particular feature of the early Paleogene climate anomalies (CIEs and hyperthermal events) is that unlike their Eocene counterparts, the Paleogene climate anomalies are much more complex and often consist of multiple minor events, creating a sawtoothlike appearance in climatic and rock magnetic proxies, similar to behavior also described in the Early Paleogene in the Tethyan region (Coccioni et al., 2012). In some instances, these anomalies have been interpreted as "multiple events anomalies," for example, Middle-Lower Danian Multiple Event (MLDME) in the Gubbio-Contessa sections (Sinnesael et al., 2016). In other settings, the same anomalies have been interpreted as discrete individual events (Barnet et al., 2019). This lead to the existence of different terminologies for synchronous anomalies, also due to the fact that the geographical distribution is not uniform, and some events are restricted to a certain region, such as it appears to be the case of the Dan-C2 event (Westerhold et al., 2011).

In this study, we correlate DSDP Site 356 with a proximal sedimentary record from the South Atlantic Walvis Ridge site (IODP Hole 1262) (see Figure 1). Both sites lie in the same region of the South Atlantic and belong to the RGR-WR system in the Cretaceous-Paleogene; however, they were separated by submarine obstacles of the Atlantic rift zone. The deep channels connecting the Brazil and Argentine Basins influenced the two sites in different ways. While Site 356 is more proximal to the deepest passage at the time, the Vema Gap (A and B in Figure 1), Site 1262 is distal, $\sim 2000 \mathrm{~km}$ away from the nearest channel. We thus expect small differences between the WR and SPP, nonetheless reflecting the same history of the evolution of the South Atlantic Ocean. Lacking stable isotope data $\left(\delta^{13} \mathrm{C}\right.$ and $\delta^{18} \mathrm{O}$ ) for Site 356 , we opt to compare the magnetic susceptibility and environmental magnetic parameters from Site 356 with the geochemical record of Site 1262.

Magnetic susceptibility is sensitive to the concentration of magnetic grains, their size, and mineralogy (Hatfield and Stoner, 2013). Though often controlled by the sum of various processes (detrital input, ocean current transport, diagenesis, etc.), they are often driven by changes in climate. S-ratio provides some insight into the magnetic mineralogy, quantifying the relative concentration of antiferromagnetic minerals in mineral mixtures (Bloemendal et al., 1988; Liu et al., 2007). The lower the S-ratio, the higher the contribution of hematite and goethite; when S-ratio approaches maximum values, the 


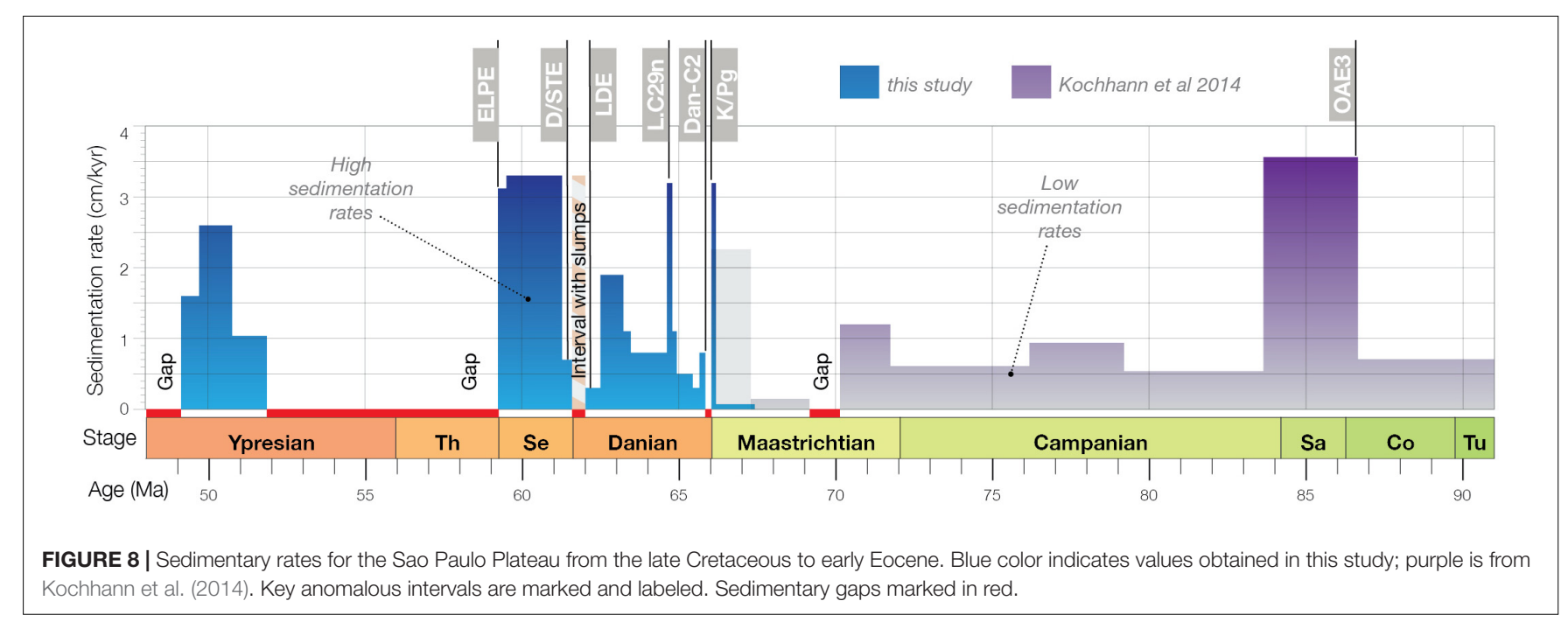

magnetic mineralogy is interpreted to be dominated by low coercivity minerals (magnetite or maghemite). $\mathrm{\kappa ARM} / \kappa$ is a magnetic grain size proxy. A closer look at the correlation between ODP Site 1262 Walvis Ridge (Barnet et al., 2019) and DSDP Site 356 reveals that anomalous magnetic susceptibility and S-ratio levels match CIEs and hyperthermals reported in the Walvis Ridge: Dan-C2 (Jehle et al., 2015), L.C29n (Barnet et al., 2019), M.C27r (Coccioni et al., 2012), LDE (Westerhold et al., 2011; Deprez et al., 2017) and D/STE (Arenillas et al., 2008). The aforementioned climate anomalies correspond to peaks in magnetic susceptibility, recovery trends in the S-ratios that follow extreme low values and high values of $\kappa \mathrm{ARM} / \kappa$. The L.C26r (Barnet et al., 2019) is difficult to identify and might be missing form 356 due to local slumping (Perch-Nielsen et al., 1977). The slumps likely induced an offset in our age model, visible as slight delays of LDE, when compared with the Walvis Ridge data. No similar anomalies can be correlated with ELPE (Coccioni et al., 2019) due to the presence of a large sedimentation gap, the onset which can be confidently correlated with ELPE, indicating a change in sedimentation occurred at the time.

We identify a series of intervals, characterized by anomalous values of the magnetic properties, that all consistently correlate with significant high- and low- sedimentation rates, or occur in the vicinity of sedimentary anomalies (Figure 8) and seem to correspond to the Dan-C2, L.C29n, M.C27r, LDE and D/STE carbon isotopic events. This seems to suggest that the anomalies may be linked to changes in deep-water circulation and/or water column instability near the Vema gap. Most anomalies occur during the Danian stage, fitting the model proposed by Voigt et al. (2013) for the onset deep-water circulation into the North Atlantic, and the model of a transition to a more connected Atlantic Ocean proposed by Batenburg et al. (2018). Deep-water circulation would be affected by the opening and enlargement of the deeper sectors of the Vema and Hunter passageways in the Rio Grande Rise region, outlined in Figure 1.

An expanded comparison of stable isotope ratios and magnetic properties throughout the Danian interval (Figure 9), reveals that the magnetic anomalies are not completely reflected in the magnetic susceptibility, showing that secondary indicators (e.g., S-Ratio) are necessary to depict a fuller picture of the anomalous magnetic properties of sediments during the CIE. That is due to the occurrence, during the CIEs, of diverse magnetic minerals that are not entirely revealed by magnetic susceptibility properties. It also appears that the early Danian CIE and magnetic anomalies are less coherent compared with the late Danian expressions, probably due to a phase of instability the water column in the South Atlantic region, either driven by the incipient deep-water circulation through the new passage (e.g., upwelling, stratification) or due to external factors such as climate anomalies (e.g., CIE and hyperthermals) disrupting the emerging ocean circulation pathways.

\section{Dan-C2 - A Marker for Paleocirculation Change?}

High-resolution studies on key sites form the Atlantic Walvis Ridge (Barnet et al., 2019) and the Pacific Shatsky Rise (Westerhold et al., 2011) show that the Early Paleocene Dan-C2 event is not a typical global hyperthermal, but rather a regional expression whilst the remaining Paleogene CIE are global and appear to be orbitally paced, occurring during maxima in the 405-kyr cycle (Barnet et al., 2019). From an ocean circulation perspective, our results indicate that during the Early Paleogene, the Rio Grande Rise - Walvis Ridge alignment was overcome, and deep-water currents from South Atlantic toward the North Atlantic were established. The geographical distribution of the Dan-C2 anomalies (Kroon et al., 2007; Quillevere et al., 2008; Westerhold et al., 2011; Coccioni et al., 2019) matches the areas that would be affected by the northward flow of South Atlantic deep waters. This raises the question of whether Dan-C2 may actually be an expression of this connectivity change in the South Atlantic. Throughout the Danian and Selandian time, the São Paulo Plateau records instability of magnetic properties and magnetic carriers in the sediments and sedimentation anomalies that match the chronology of CIEs and hyperthermals. 

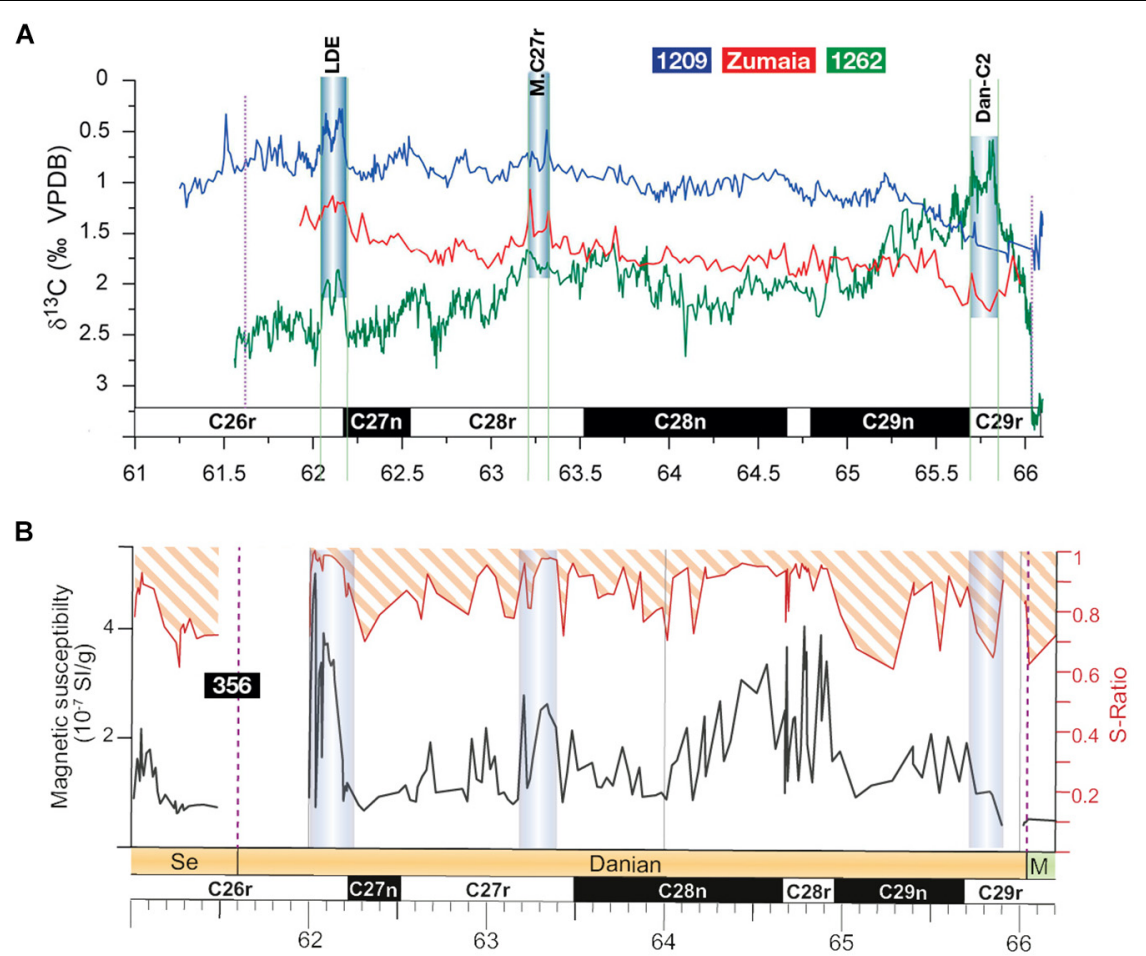

C

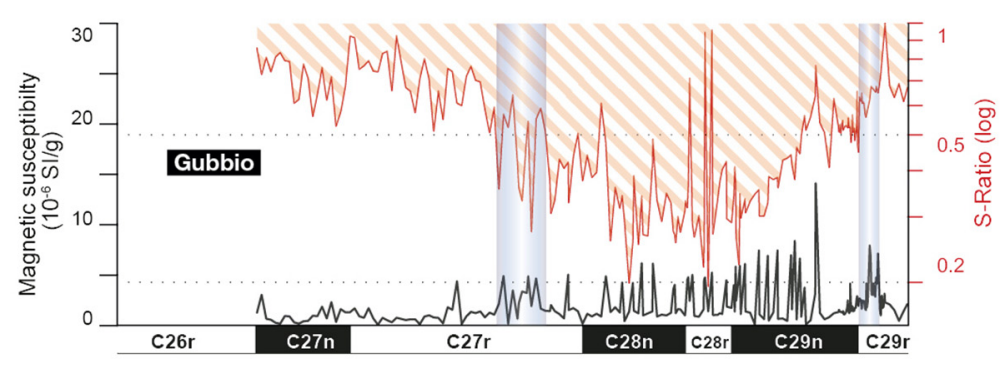

D

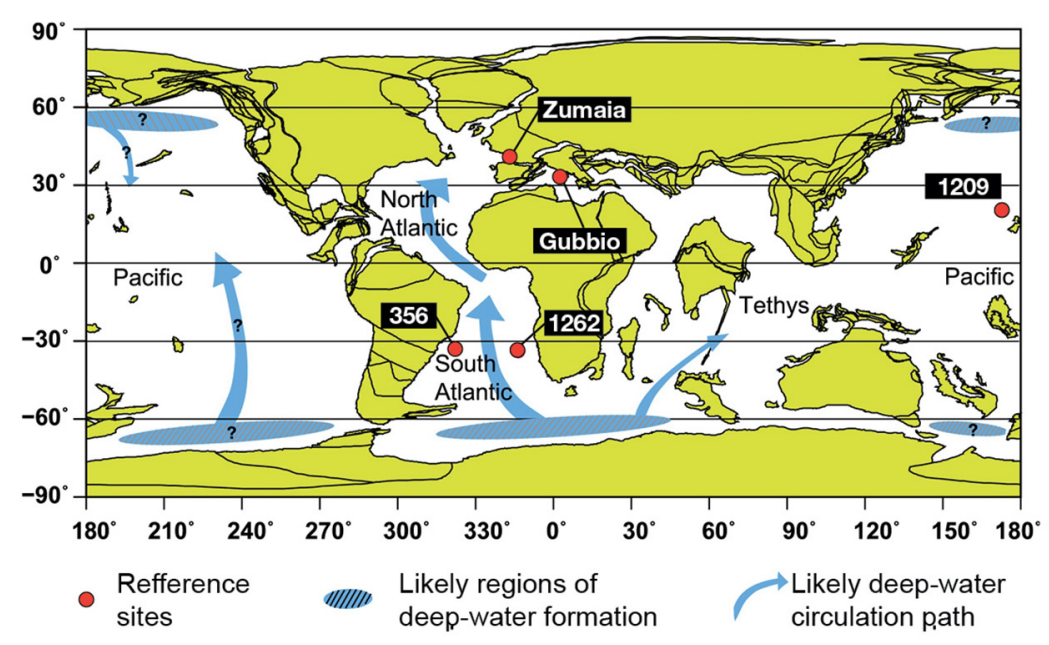

FIGURE 9 | Danian anomalies in the sedimentary record. Please note the discordant trends that correspond to the Dan-C2 event in carbon isotopes curves from Atlantic, Pacific and Tethys regions [(A) from Dinarès-Turell et al. (2014)] and the environmental magnetism results from South Atlantic [(B) site 356, this study] and Tethys region [(C) Gubbio, after Coccioni et al., 2012] and the geographic location of the compared sites [(D) after Littler et al., 2014]. 


\section{CONCLUSION}

We studied the sediments of DSDP Site 356 Leg 39, set on the São Paulo Plateau on the edge of the Rio Grande Rise in the South Atlantic. The position of the site next to the last obstacles to unrestricted ocean circulation meant that it preserves a sedimentary record of the onset and development of the Atlantic Ocean Circulation. We developed a new, improved age model with magnetostratigraphy for the Latest Maastrichtian - Early Lutetian interval (68-46 Ma) to shed light on the time interval where the RGR-WR was progressively breached, constraining the sedimentary rates as an indicator of bottom current activity. We find sharp anomalies in the early Paleogene, coinciding with rapid fluctuations in the magnetic properties of the sediment. Correlations with known hyperthermal events documented in the nearby Walvis Ridge indicate a potential link between climatic anomalies and paleocirculation. Drastic changes in the general sedimentation trends begin after the Dan-C2 anomaly, which we interpret as an indirect result of the change in connectivity following the breach of southern deep waters across the RGRWR. We hypothesize that Dan-C2, given that it does not represent a true hyperthermal event, it rather marks a drastic change in bottom water conditions following the initiation of a deepwater connection in the South Atlantic Ocean, as the Atlantic Ocean Circulation gradually replaces the Tethys circumequatorial oceanic circulation and ultimately leads to the onset of the modern Atlantic Meridional Overturning Circulation.

\section{DATA AVAILABILITY STATEMENT}

The raw data supporting the conclusions of this article will be made available by the authors, without undue reservation.

\section{AUTHOR CONTRIBUTIONS}

LJ requested samples, conceived and funded the study. DP and JM designed and conducted the research and wrote

\section{REFERENCES}

Arai, M. (1988). Geochemical reconnaissance of the mid-cretaceous anoxic event in the Santos Basin, Brazil. Rev. Bras. Geociencias 18, 273-282. doi: 10.25249/ 0375-7536.1988273282

Arenillas, I., Molina, E., Ortiz, S., and Schmitz, B. (2008). Foraminiferal and $\delta 13 \mathrm{C}$ isotopic event- stratigraphy across the Danian-Selandian transition at Zumaya (northern Spain): chronostratigraphic implications. Terra Nova 20, 38-44. doi: 10.1111/j.1365-3121.2007.00784.x

Avilla, L. S., Candeiro, C. R., Buckup, P., and Bergqvist, L. P. (2002). Gondwana biogeography: a phylogenetic approach. An. Acad. Bras. Cienc. 74, 365-365. doi: 10.1590/s0001-37652002000200018

Banerjee, S. K., King, J., and Marvin, J. (1981). A rapid method for magnetic granulometry with applications to environmental studies. Geophys. Res. Lett. 8, 333-336. doi: 10.1029/gl008i004p00333

Barnet, J. S., Littler, K., Westerhold, T., Kroon, D., Leng, M. J., Bailey, I., et al. (2019). A high-fidelity benthic stable isotope record of late cretaceous-early eocene climate change and carbon-cycling. Paleoceanogr. Paleoclimatol. 34, 672-691. doi: 10.1029/2019PA003556

Batenburg, S. J., Voigt, S., Friedrich, O., Osborne, A. H., Bornemann, A., Klein, T., et al. (2018). Major intensification of Atlantic overturning circulation at the onset of Paleogene greenhouse warmth. Nat. Commun. 9:4954. the manuscript. PJ helped in acquiring and processing the paleomagnetic data, and contributed to the drafting of the manuscript. All authors contributed to the article and approved the submitted version.

\section{FUNDING}

This work is part of the Coordenação de Aperfeiçoamento de Pessoal de Nível Superior (CAPES) - Finance Code 001, Ciência do Mar II. DP acknowledges the Fundação de Amparo a Pesquisa do Estado de São Paulo (FAPESP) for financial support through grant 2018/20733-6. LJ acknowledges FAPESP projects 2016/24946-9 and 2018/17061-6. This work has been (partially) performed at USPMag lab at Instituto de Astronomia, Geofísica e Ciências Atmosféricas (IAG) at Universidade de São Paulo (USP) funded by CAPES/FAPESP/CNPQ.

\section{ACKNOWLEDGMENTS}

The authors wish to sincerely thank the staff of USPMAG for access to the facilities and help with the acquisition and processing of the data. The authors thank the staff of Fort Hoofddijk Paleomagnetic Lab - Utrecht University and Mark Dekkers, in particular for helping with the preparation and acquisition of the data. The authors thank the staff of MARUM University of Bremen and Holger Kuhlmann, in particular for facilitating sampling of the DSDP core.

\section{SUPPLEMENTARY MATERIAL}

The Supplementary Material for this article can be found online at: https://www.frontiersin.org/articles/10.3389/feart. 2020.00375/full\#supplementary-material

FIGURE S1 | Supplementary paleomagnetic results. Inclination unflattening for samples from the first quality group (q1).

Battle, M., Bender, M. L., Tans, P. P., White, J. W., Ellis, J. T., Conway, T., et al. (2000). Global carbon sinks and their variability inferred from atmospheric O2 and 813 C. Science 287, 2467-2470. doi: 10.1126/science.287.5462.2467

Bloemendal, J., King, J. W., Hall, F. R., and Doh, S.-J. (1992). Rock magnetism of late neogene and pleistocene deep-sea sediments: relationship to sediment source, diagenetic processes, and sediment lithology. J. Geophys. Res. 97, 43614375. doi: 10.1029/91JB03068

Bloemendal, J., Lamb, B., and King, J. (1988). Paleoenvironmental implications of rock-magnetic properties of late quaternary sediment cores from the eastern equatorial Atlantic. Paleoceanography 3, 61-87. doi: 10.1029/PA003i001p0 0061

Bryden, H. L., and Imawaki, S. (2001). Chapter 6.1 Ocean heat transport. Int. Geophys. 77, 455-474. doi: 10.1016/S0074-6142(01)80134-0

Buckley, J. P., Bosence, D., and Elders, C. (2015). Tectonic setting and stratigraphic architecture of an early Cretaceous lacustrine carbonate platform, Sugar Loaf High, Santos Basin, Brazil. Geol. Soc. Spec. Publ. 418, 175-191. doi: 10.1144/ SP418.13

Buckley, M. W., and Marshall, J. (2016). Observations, inferences, and mechanisms of the Atlantic Meridional Overturning Circulation: a review. Rev. Geophys. 54, 5-63. doi: 10.1002/2015rg000493

Carvallo, C., Muxworthy, A. R., and Dunlop, D. J. (2006). First-order reversal curve (FORC) diagrams of magnetic mixtures: micromagnetic models and 
measurements. Phys. Earth Planet. Inter. 154, 308-322. doi: 10.1016/j.pepi. 2005.06.017

Chaboureau, A. C., Guillocheau, F., Robin, C., Rohais, S., Moulin, M., and Aslanian, D. (2013). Paleogeographic evolution of the central segment of the South Atlantic during Early Cretaceous times: paleotopographic and geodynamic implications. Tectonophysics 604, 191-223. doi: 10.1016/j.tecto.2012.08.025

Chadima, M., and Hrouda, F. (2006). Remasoft 3.0 a user-friendly paleomagnetic data browser and analyzer. Trav. Géophys. 27, 20-21.

Chang, L., Winklhofer, M., Roberts, A. P., Heslop, D., Florindo, F., Dekkers, M. J., et al. (2013). Low-temperature magnetic properties of pelagic carbonates: oxidation of biogenic magnetite and identification of magnetosome chains. J. Geophys. Res. Solid Earth 118, 6049-6065. doi: 10.1002/2013jb010381

Chen, X., and Tung, K. K. (2018). Global surface warming enhanced by weak Atlantic overturning circulation. Nature 559, 387-391. doi: 10.1038/s41586018-0320-y

Coccioni, R., Bancalà, G., Catanzarit, R., Fornaciari, E., Frontalini, F., Giusberti, L., et al. (2012). An integrated stratigraphic record of the Palaeocene-lower Eocene at Gubbio (Italy): new insights into the early Palaeogene hyperthermals and carbon isotope excursions. Terra Nova 24, 380-386. doi: 10.1111/j.1365-3121. 2012.01076.x

Coccioni, R., Frontalini, F., Catanzariti, R., Jovane, L., Rodelli, D., Rodrigues, I. M., et al. (2019). Paleoenvironmental signature of the selandian-thanetian transition event (STTE) and early late paleocene event (ELPE) in the Contessa Road section (western Neo-Tethys). Palaeogeogr. Palaeoclimatol. Palaeoecol. 523, 62-77. doi: 10.1016/J.PALAEO.2019.03.023

Cogne, N., Gallagher, K., Cobbold, P. R., Riccomini, C., and Gautheron, C. (2012). Post-breakup tectonics in southeast Brazil from thermochronological data and combined inverse-forward thermal history modeling. J. Geophys. Res. B Solid Earth 117:B11413. doi: 10.1029/2012JB009340

Davison, I., Anderson, L., and Nuttall, P. (2012). Salt deposition, loading and gravity drainage in the Campos and Santos salt basins. Geol. Soc. Spec. Publ. 363, 159-174. doi: 10.1144/sp363.8

de Oliveira, V. C. B., Silva, C. M. D. A., Borghi, L. F., and Carvalho, I. D. S. (2019). Lacustrine coquinas and hybrid deposits from rift phase: pre-Salt, lower Cretaceous, Campos Basin, Brazil. J. South Am. Earth Sci. 95:102254. doi: 10.1016/j.jsames.2019.102254

Deprez, A., Jehle, S., Bornemann, A., and Speijer, R. P. (2017). Differential response at the seafloor during Palaeocene and Eocene ocean warming events at Walvis Ridge, Atlantic Ocean (ODP Site 1262). Terra Nova 29, 71-76. doi: 10.1111/ter. 12250

Dinarès-Turell, J., Westerhold, T., Pujalte, V., Rohl, U., and Kroon, D. (2014). Astronomical calibration of the Danian stage (Early Paleocene) revisited: settling chronologies of sedimentary records across the Atlantic and Pacific Oceans. Earth Planet. Sci. Lett. 405, 119-131. doi: 10.1016/j.epsl.2014.08.027

Donnadieu, Y., Puceat, E., Moiroud, M., Guillocheau, F., and Deconinck, J. F. (2016). A better-ventilated ocean triggered by Late Cretaceous changes in continental configuration. Nat. Commun. 7:10316. doi: 10.1038/ncomms10316

Dutkiewicz, A., Dietmar Müller, R., Hogg, A. M. C., and Spence, P. (2016). Vigorous deep-sea currents cause global anomaly in sediment accumulation in the Southern Ocean. Geology 44, 663-666. doi: 10.1130/g38143.1

Egli, R. (2013). VARIFORC: an optimized protocol for calculating non-regular first-order reversal curve (FORC) diagrams. Glob. Planet. Change 110, 302-320. doi: 10.1016/j.gloplacha.2013.08.003

Frank, T. D., and Arthur, M. A. (1999). Tectonic forcings of Maastrichtian oceanclimate evolution. Paleoceanography 14, 103-117. doi: 10.1029/1998PA900017

Fu, Y., Von Dobeneck, T., Franke, C., Heslop, D., and Kasten, S. (2008). Rock magnetic identification and geochemical process models of greigite formation in quaternary marine sediments from the gulf of Mexico (iodp hole u1319a). Earth Planet. Sci. Lett. 275, 233-245. doi: 10.1016/j.epsl.2008.07.034

Gehring, A. U., Fischer, H., Louvel, M., Kunze, K., and Weidler, P. G. (2009). High temperature stability of natural maghemite: a magnetic and spectroscopic study. Geophys. J. Int. 179, 1361-1371. doi: 10.1111/j.1365-246X.2009.04348.x

Gilmour, I., Jolley, D., Kemp, D., Kelley, S., Gilmour, M., Daly, R., et al. (2014). “The early Danian hyperthermal event at Boltysh (Ukraine): relation to CretaceousPaleogene boundary events," in Volcanism, Impacts, and Mass Extinctions: Causes and Effects, eds G. Keller and A. C. Kerr (Boulder, CO: Geological Society of America), 133-146. doi: 10.1130/2014.2505(06
Gradstein, F., and Ogg, J. (2006). Ts-creator ${ }^{\odot}$ - chronostratigraphic data base and visualisation: cenozoic- mesozoic-paleozoic integrated stratigraphy and usergenerated time scale graphics and charts. Geoarabia 11, 181-184.

Grassl, H. (2001). Climate and oceans. Int. Geophys. 77, 3-9.

Gruber, N., Keeling, C. D., and Bates, N. R. (2002). Interannual variability in the North Atlantic ocean carbon sink. Science 298, 2374-2378. doi: 10.1126/science. 1077077

Guardado, L. R., Gamboa, L. A. P., and Lucchesi, C. F. (1989). “Petroleum geology of the Campos Basin, Brazil, a model for a producing Atlantic type basin: PART 1," in Divergent/Passive Margin Basins, Vol. 48, eds J. D. Edwards and P. A. Santogrossi (Tulsa: AAPG), 3-36.

Harrison, R. J., and Feinberg, J. M. (2008). FORCinel: an improved algorithm for calculating first-order reversal curve distributions using locally weighted regression smoothing. Geochem. Geophys. Geosyst. 9:Q05016. doi: 10.1029/ 2008GC001987

Hatfield, R. G., and Stoner, J. S. (2013). "Magnetic proxies and susceptibility," in Encyclopedia of Quaternary Science, 2nd Edn, ed. S. Elias (Amsterdam: Elsevier), 884-898. doi: 10.1016/B978-0-444-53643-3.00307-1

Herbin, J. P., Muller, C., Graciansky, P. C. D., Jacquin, T., Magniez-Jannin, F., and Unternehr, P. (1987). Cretaceous anoxic events in the South Atlantic. Rev. Bras. Geociencias 17, 92-99. doi: 10.25249/0375-7536.19879299

Hernández-Molina, F. J., Stow, D. A. V., Alvarez-Zarikian, C. A., Acton, G., Bahr, A., Balestra, B., et al. (2014). Onset of Mediterranean outflow into the North Atlantic. Science 344, 1244-1250. doi: 10.1126/science. 1251306

Hillaire-Marcel, C., and De Vernal, A. (2007). Proxies in Late Cenozoic Paleoceanography. Amsterdam: Elsevier.

Hull, P. M., Bornemann, A., Penman, D. E., Henehan, M. J., Norris, R. D., Wilson, P. A., et al. (2020). On impact and volcanism across the Cretaceous-Paleogene boundary. Science 367, 266-272.

Jehle, S., Bornemann, A., Deprez, A., and Speijer, R. P. (2015). The impact of the latest danian event on planktic foraminiferal faunas at ODP Site 1210 (Shatsky Rise, Pacific Ocean). PLoS One 10:e0141644. doi: 10.1371/journal. pone.0141644

King, J., Banerjee, S. K., Marvin, J., and Ozdemir, O. (1982). A comparison of different magnetic methods for determining the relative grain size of magnetite in natural materials: some results from lake sediments. Earth Planet. Sci. Lett. 59, 404-419. doi: 10.1016/0012-821X(82)90142-X

Kirschvink, J. L. (1980). The least-squares line and plane and the analysis of palaeomagnetic data. Geophys. J. Int. 62, 699-718. doi: 10.1111/j.1365-246X. 1980.tb02601.x

Kirschvink, J. L., Kopp, R. E., Raub, T. D., Baumgartner, C. T., and Holt, J. W. (2008). Rapid, precise, and high-sensitivity acquisition of paleomagnetic and rock-magnetic data: development of a low-noise automatic sample changing system for superconducting rock magnetometers. Geochem. Geophys. Geosyst. 9:Q05Y01. doi: 10.1029/2007GC001856

Kochhann, K. G. D., Lopes, F. M., Krahl, G., Aguiar, E., and Fauth, G. (2014). Late cretaceous-early paleogene (Turonian? to early Danian) planktic foraminifera from DSDP site 356: a biostratigraphic reappraisal. Rev. Bras. Paleontol. 17, 157-168. doi: 10.4072/rbp.2014.2.04

Koutsoukos, E. A. (1992). Late aptian to maastrichtian foraminiferal biogeography and palaeoceanography of the Sergipe basin, Brazil. Palaeogeogr. Palaeoclimatol. Palaeoecol. 92, 295-324. doi: 10.1016/0031-0182(92)90089-n

Krahl, G., Koutsoukos, E. A., and Fauth, G. (2017). Paleocene planktonic foraminifera from DSDP Site 356, South Atlantic: paleoceanographic inferences. Mar. Micropaleontol. 135, 1-14. doi: 10.1016/j.marmicro.2017.07. 001

Kroon, D., Zachos, J., Blum, P., Bowles, J., Gaillot, P., Hasegawa, T., et al. (2007). Leg 208 Synthesis: Cenozoic Climate Cycles and Excursions. College Station, TX: Ocean Drilling Program.

Kumar, N., and Gamboa, L. A. P. (1979). Evolution of the Sao Paulo Plateau (southeastern Brazilian margin) and implications for the early history of the South Atlantic. GSA Bull. 90, 281-293.

Littler, K., Röhl, U., Westerhold, T., and Zachos, J. C. (2014). A highresolution benthic stable-isotope record for the South Atlantic: implications for orbital-scale changes in Late Paleocene-Early Eocene climate and carbon cycling. Earth Planet. Sci. Lett. 401, 18-30. doi: 10.1016/j.epsl.2014. 05.054 
Liu, Q., Roberts, A. P., Torrent, J., Horng, C.-S., and Larrasoaña, J. C. (2007). What do the HIRM and S-ratio really measure in environmental magnetism? Geochem. Geophys. Geosyst. 8:Q09011. doi: 10.1029/2007GC001717

Liu, X. M., Shaw, J., Jiang, J. Z., Bloemendal, J., Hesse, P., Rolph, T., et al. (2010). Analysis on variety and characteristics of maghemite. Sci. China Earth Sci. 53, 1153-1162. doi: 10.1007/s11430-010-0030-2

Mai, H., Hildebrand-Habel, T., Perch-Nielsen, K. V. S., and Willems, H. (1998). Paleocene coccospheres from DSDP Leg 39, Site 356, Sao Paulo Plateau, S Atlantic Ocean. J. Nannoplankton Res. 20, 21-29.

Mohriak, W., Nemcok, M., and Enciso, G. (2008). South Atlantic divergent margin evolution: rift-border uplift and salt tectonics in the basins of SE Brazil. Geol. Soc. Spec. Publ. 294, 365-398. doi: 10.1144/SP294.19

Mohriak, W. U. (2003). "Bacias sedimentares da margem continental Brasileira," in Geologia, Tectonica e Recursos Minerais do Brasil, eds L. Bizzi, C. Schobbenhaus, R. Vidotti, and J. Goncalves (Brasil: CPRM), 87-165.

Moskowitz, B. M. (2007). "Magnetization, anhysteretic remanent," in Encyclopedia of Geomagnetism and Paleomagnetism, eds D. Gubbins and E. Herrero-Bervera (Dordrecht: Springer).

Mullender, T. A. T., Frederichs, T., Hilgenfeldt, C., de Groot, L. V., Fabian, K., and Dekkers, M. J. (2016). Automated paleomagnetic and rock magnetic data acquisition with an in-line horizontal " $2 \mathrm{G}$ ” system. Geochem. Geophys. Geosyst. 17, 3546-3559. doi: 10.1002/2016GC006436

Mullender, T. A. T., Velzen, A. J., and Dekkers, M. J. (1993). Continuous drift correction and separate identification of ferrimagnetic and paramagnetic contributions in thermomagnetic runs. Geophys. J. Int. 114, 663-672. doi: 10. 1111/j.1365-246X.1993.tb06995.x

Murphy, D. P., and Thomas, D. J. (2013). The evolution of Late Cretaceous deepocean circulation in the Atlantic basins: neodymium isotope evidence from South Atlantic drill sites for tectonic controls. Geochem. Geophys. Geosyst. 14, 5323-5340. doi: 10.1002/2013GC004889

Ogg, J. G., Ogg, G. M., and Gradstein, F. M. (2016). A Concise Geologic Time Scale: 2016. Amsterdam: Elsevier.

Ohmoto, H. (2003). Nonredox transformations of magnetite-hematite in hydrothermal systems. Econ. Geol. 98, 157-161. doi: 10.2113/gsecongeo.98.1. 157

Opdyke, N. D., and Channell, J. E. (1996). "Magnetic stratigraphy," in International Geophysics, Vol. 64, eds N. D. Opdyke and J. E. Channell (London: Academic Press), 49-73. doi: 10.1016/S0074-6142(06)80006-9

Ozdemir, O., and Banerjee, S. K. (1984). High temperature stability of maghemite ( $\gamma$-Fe2O3). Geophys. Res. Lett. 11, 161-164. doi: 10.1029/GL011i003p00161

Perch-Nielsen, K., Supko, P., Boersma, A., Carlson, R., Dinkelman, M., Fodor, R., et al. (1977). Site 356: Sao Paulo Plateau. Initial Rep. Deep Sea Drill. Proj. 39, $141-230$.

Pérez-Díaz, L., and Eagles, G. (2017). South Atlantic paleobathymetry since early Cretaceous. Sci. Rep. 7:11819. doi: 10.1038/s41598-017-11959-7

Pietzsch, R., Oliveira, D. M., Tedeschi, L. R., Queiroz Neto, J. V., Figueiredo, M. F., Vazquez, J. C., et al. (2018). Palaeohydrology of the Lower Cretaceous pre-salt lacustrine system, from rift to post- rift phase, Santos Basin, Brazil. Palaeogeogr. Palaeoclimatol. Palaeoecol. 507, 60-80. doi: 10.1016/j.palaeo.2018.06.043

Quillevere, F., Aubry, M. P., Norris, R. D., and Berggren, W. A. (2002). Paleocene oceanography of the eastern subtropical Indian Ocean: an integrated magnetobiostratigraphic and stable isotope study of ODP Hole 761B (Wombat Plateau). Palaeogeogr. Palaeoclimatol. Palaeoecol. 184, 371-405. doi: 10.1016/ S0031-0182(02)00275-4

Quillevere, F., Norris, R. D., Kroon, D., and Wilson, P. A. (2008). Transient ocean warming and shifts in carbon reservoirs during the early danian. Earth Planet. Sci. Lett. 265, 600-615. doi: 10.1016/j.epsl.2007.10.040

Roberts, A. P., Liu, Q., Rowan, C. J., Chang, L., Carvallo, C., Torrent, J., et al. (2006). Characterization of hematite ( $\alpha$-fe2o3), goethite ( $\alpha$-feooh), greigite (fe $3 \mathrm{~s} 4)$, and pyrrhotite (fe7s8) using first-order reversal curve diagrams. J. Geophys. Res. Solid Earth 111:B12S35.

Robinson, S. A., Murphy, D. P., Vance, D., and Thomas, D. J. (2010). Formation of "Southern Component Water" in the Late Cretaceous: evidence from Ndisotopes. Geology 38, 871-874. doi: 10.1130/g31165.1

Robinson, S. A., and Vance, D. (2012). Widespread and synchronous change in deep-ocean circulation in the North and South Atlantic during the Late Cretaceous. Paleoceanography 27:1102.

Schulte, P., Schwark, L., Stassen, P., Kouwenhoven, T. J., Bornemann, A., and Speijer, R. P. (2013). Black shale formation during the Latest Danian Event and the Paleocene-Eocene Thermal Maximum in central Egypt: two of a kind? Palaeogeogr. Palaeoclimatol. Palaeoecol. 371, 9-25. doi: 10.1016/j.palaeo.2012. 11.027

Silva, R., de Moraes Rios-Netto, A., Silva, S. C., Valle, B., Borghi, L., and AbbotsQueiroz, F. (2020). Middle Cretaceous calcareous nannofossils from the cored well UFRJ-2-LRJ-01-SE, Sergipe-Alagoas Basin, Brazil: new biostratigraphy and paleobiogeographic inferences. Cretac. Res. 106:104245. doi: 10.1016/j.cretres. 2019.104245

Sinnesael, M., De Vleeschouwer, D., Coccioni, R., Claeys, P., Frontalini, F., Jovane, L., et al. (2016). High-resolution multiproxy cyclostratigraphic analysis of environmental and climatic events across the Cretaceous-Paleogene boundary in the classic pelagic succession of Gubbio (Italy). Spec. Pap. Geol. Soc. Am. 524, 115-137. doi: 10.1130/2016.2524(09)

Snowball, I. F. (1997). Gyroremanent magnetization and the magnetic properties of greigite-bearing clays in southern Sweden. Geophys. J. Int. 129, 624-636. doi: 10.1111/j.1365-246x.1997.tb04498.x

Sprong, J., Kouwenhoven, T. J., Bornemann, A., Schulte, P., Stassen, P., Steurbaut, E., et al. (2012). Characterization of the Latest Danian Event by means of benthic foraminiferal assemblages along a depth transect at the southern Tethyan margin (Nile Basin, Egypt). Mar. Micropaleontol. 86-87, 15-31. doi: 10.1016/j.marmicro.2012.01.001

Supko, P., and Perch-Nielsen, K. (1977). "General synthesis of central and South Atlantic drilling results, Leg 39, Deep Sea Drilling Project," in Initial Reports of the Deep-Sea Drilling Project, Vol. 39, eds C. C. von der Borch and J. G. Sclater (Washington, DC: US Government Printing Office), 1099-1131.

Supko, P., Perch-Nielsen, K., and Carlson, R. (1977). Introduction and explanatory notes, Leg 39, Deep Sea Drilling Project, Initial Report. Deep Sea Drill. Proj. 39, $1-2$.

Tauxe, L., Kodama, K. P., and Kent, D. V. (2008). Testing corrections for paleomagnetic inclination error in sedimentary rocks: a comparative approach. Phys. Earth Planet. Inter. 169, 152-165. doi: 10.1016/j.pepi.2008.05.006

Tedeschi, L. R., Jenkyns, H. C., Robinson, S. A., Sanjinés, A. E., Viviers, M. C., Quintaes, C. M., et al. (2017). New age constraints on Aptian evaporites and carbonates from the South Atlantic: implications for oceanic anoxic event 1a. Geology 45, 543-546. doi: 10.1130/G38886.1

Thiede, J. (1977). Sedimentary structures in pelagic and hemipelagic sediments from the central and southern Atlantic Ocean (Deep-Sea Drilling Project Leg 39). Initial Rep. Deep Sea Drill. Proj. 39, 407-415.

Voigt, S., Jung, C., Friedrich, O., Frank, M., Teschner, C., and Hoffmann, J. (2013). Tectonically restricted deep-ocean circulation at the end of the Cretaceous greenhouse. Earth Planet. Sci. Lett. 369-370, 169-177. doi: 10.1016/j.epsl.2013. 03.019

Wagreich, M. (2012). "OAE 3" - Regional Atlantic organic carbon burial during the Coniacian-Santonian. Clim. Past 8, 1447-1455. doi: 10.5194/cp-8-1447-2012

Wanderley, M. D., and Pedrosa, F. (2017). Calcareous nannoplankton from the continuous K-Pg Boundary of the São Paulo Plateau: a biostratigraphic and paleoecological approach to the mass extinction. Palaeogeogr. Palaeoclimatol. Palaeoecol.

Westerhold, T., Rhl, U., Donner, B., McCarren, H. K., and Zachos, J. C. (2011). A complete high-resolution Paleocene benthic stable isotope record for the central Pacific (ODP Site 1209). Paleoceanography 26, 1-13. doi: 10.1029/ 2010PA002092

Woodruff, F., and Savin, S. M. (1989). Miocene deepwater oceanography. Paleoceanography 4, 87-140. doi: 10.1029/pa004i001p00087

Zijderveld, J. D. A. (2013). AC demagnetization of rocks: analysis of results. Dev. Solid Earth Geophys. 3, 254-286. doi: 10.1016/b978-1-4832-2894-5.50 049-5

Conflict of Interest: The authors declare that the research was conducted in the absence of any commercial or financial relationships that could be construed as a potential conflict of interest.

Copyright (c) 2020 Palcu, Muraszko, Jaqueto and Jovane. This is an open-access article distributed under the terms of the Creative Commons Attribution License (CC BY). The use, distribution or reproduction in other forums is permitted, provided the original author(s) and the copyright owner(s) are credited and that the original publication in this journal is cited, in accordance with accepted academic practice. No use, distribution or reproduction is permitted which does not comply with these terms. 